Research Article/Araştırma Makalesi

Encountered Problems by Science Teachers in the Field of Engineering and Design Skills and Suggestions for Solutions

\author{
Hasan BAKIRCI *1 (D) Yusuf KAPLAN *2 (D) \\ ${ }^{1}$ Van Yüzüncü Yıl University, Faculty of Education, Van, Turkey, hasanbakirci09@gmail.com \\ ${ }^{2}$ Ministry of National Education, Mardin, Turkey, yusufkaplan2003@gmail.com \\ *Corresponding Author: hasanbakirci09@gmail.com
}

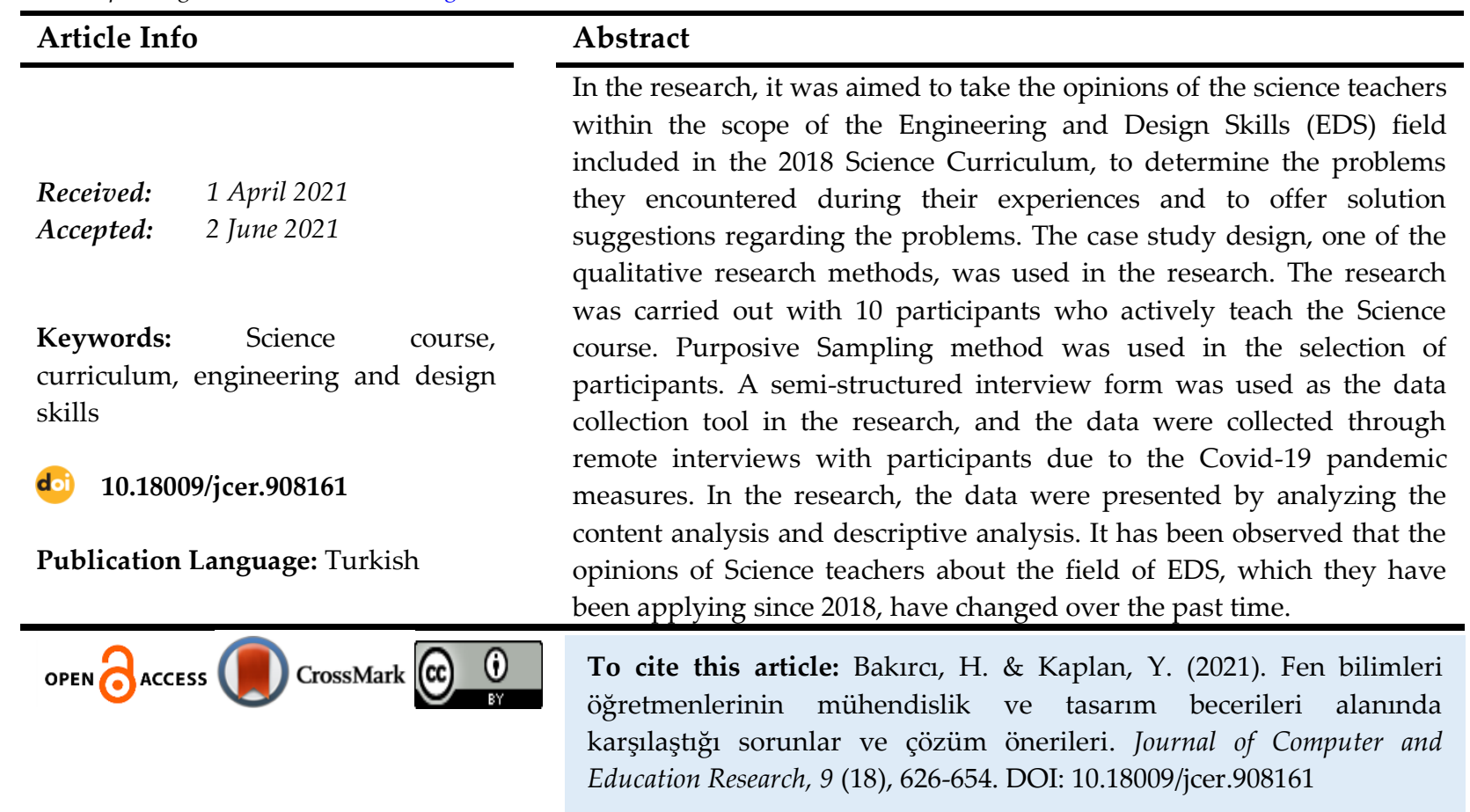

\title{
Fen Bilimleri Öğretmenlerinin Mühendislik ve Tasarım Becerileri Alanında Karşılaştığı Sorunlar ve Çözüm Önerileri
}

\begin{tabular}{|c|c|}
\hline Makale Bilgisi & $\ddot{O} z$ \\
\hline & $\begin{array}{l}\text { Araştırmada Fen Bilimleri öğretmenlerinin } 2018 \text { Fen Bilimleri Dersi } \\
\text { Öğretim Programı'nda yer alan Mühendislik ve Tasarım Becerileri alanı }\end{array}$ \\
\hline 1 Nisan 2021 & kapsamında görüşlerinin alınması, deneyimleri sırasında karşılaştıkları \\
\hline 2 Haziran 2021 & $\begin{array}{l}\text { sorunların belirlenmesi ve bu sorunlara dair çözüm önerilerinin } \\
\text { sunulması amaçlanmıştır. Araştırmada, nitel araştırma yöntemlerinden } \\
\text { durum çalışması deseni kullanılmıştır. Araştırma, Fen Bilimleri dersini }\end{array}$ \\
\hline $\begin{array}{l}\text { Anahtar kelimeler: Fen bilimleri } \\
\text { dersi, öğretim programı, mühendislik } \\
\text { tasarım becerileri }\end{array}$ & $\begin{array}{l}\text { aktif olarak okutan } 10 \text { katılımcı ile yapılmıştır. Katılımcı seçiminde } \\
\text { amaçsal örnekleme yöntemi kullanılmıştır. Araştırmada veri toplama } \\
\text { aracı olarak yarı yapılandırılmış mülakat formu kullanılmış, veriler } \\
\text { Covid-19 pandemisi önlemleri ısığında katılımcılarla uzaktan görüsme }\end{array}$ \\
\hline doi $10.18009 /$ jcer.908161 & $\begin{array}{l}\text { yapılarak toplanmıştır. Araştırmada veriler içerik analizi ve betimsel } \\
\text { analize tabi tutularak sunulmuştur. Fen Bilimleri öğretmenlerinin } 2018\end{array}$ \\
\hline Yayım Dili: Türkçe & $\begin{array}{l}\text { yılından beri uygulamakta oldukları Mühendislik ve Tasarım Becerileri } \\
\text { alanı hakkındaki görüşlerinin geçen zaman zarfında değiştiği } \\
\text { görülmüștür. }\end{array}$ \\
\hline
\end{tabular}




\title{
Summary
}

\section{Encountered Problems by Science Teachers in the Field of Engineering and Design Skills and Suggestions for Solutions}

\author{
Hasan BAKIRCI *1 (iD) Yusuf KAPLAN *2 (iD \\ ${ }^{1}$ Van Yüzüncü Yıl University, Faculty of Education, Van, Turkey, hasanbakirci09@gmail.com \\ ${ }^{2}$ Ministry of National Education, Mardin, Turkey, yusufkaplan2003@gmail.com \\ Corresponding Author: hasanbakirci09@gmail.com
}

\section{Introduction}

Every country or every society should increase the quality of education in science and technology in order to maintain dynamism by giving the necessary importance to science and technology education. In order to increase this quality and realize a sustainable development, science education programs should catch up with the future. In the last century, some attempts have been made to improve the quality of science education. Most attempts to keep up with the changes have been in the form of updating or changing the curriculum (Ayas, 1995; Ayas, Çepni \& Akdeniz, 1993). In the field of science education, starting from 2000, Ministry of National Education (MoNE) renewed its curricula in 2005, 2013 and 2018. By 2017, MoNE updated the curriculum of many courses. Science course was also included in these courses. Within the scope of the changes, the 2017 Science Course Draft Curriculum was published, and in line with the criticism and opinions received about the program, the program was finalized in 2018. In this context, in addition to Scientific Process Skills and Life Skills, Engineering and Design Skills (EDS) field was added to the 2018 science course curriculum for the first time. In this research, a literature review was conducted on teachers' views on the field of EDS included in the 2018 science course curriculum. When the literature is examined, it is seen that the studies on teaching programs have increased in recent years. Especially after 2017, the inclusion of EDS in the 2018 science course curriculum has increased the interest in the curriculum. According to the findings obtained from the literature review, it can be said that the studies on EDS in the 2018 science course curriculum are quite limited. Since the studies examining the problems teachers encounter during the EDS practices in the 2018 science course curriculum are quite limited, it was necessary to conduct research on this subject and to eliminate this deficiency in the literature. Therefore, it has become necessary to obtain teachers' opinions in the context of 
experiences within the scope of EDS. In the study, it was aimed to identify the problems faced by science teachers in their EDS practices under separate headings and to formulate solution suggestions to these problems. At the same time, it is expected that the research results to be reached will shed light on scientific studies on this subject and contribute to the updates to be made in the curriculum.

\section{Method}

Case study design, one of the qualitative research methods, was used in the research. The case study design offers the opportunity to examine a case or an event in depth through questions such as 'why' and 'how' (Çepni, 2018). The research includes the experiences of the teachers who teach the Science Course in the practices of EDS in the 2018 science course curriculum and the determination of the problems encountered. This research, in the 20202021 academic year, was carried out in Turkey's Mardin province located in the Southeastern Anatolia Region. A semi-structured interview form consisting of 9 questions was used as a data collection tool in the study. The data collection process was carried out by taking remote audio recordings to prevent the risk of transmission due to the Covid-2019 pandemic. Descriptive and content analysis methods were used in analyzing the data obtained in the study in order to express the opinions of the participants in depth and directly, and to examine the data obtained from the participants in depth. The formula developed by Miles and Huberman (1994) was used to determine the points that could and could not be agreed for the analyzes performed. As a result, the coefficient of agreement percentage between researchers was found to be 0.91 (Miles \& Huberman, 1994).

\section{Results}

In the research, it was determined that the participants had positive and negative opinions about EDS. It is among the positive and negative opinions brought to the fore by the participants that EDS improves problem solving skills and the relationship of EDS with STEM is not clear. It is among the positive and negative opinions that the subject is guiding and limiting in terms of how the subject and attainments of the course guides the participants in EDS practices. At the same time, the majority of the participants suggested that the attainments should be reorganized. A great majority of the participants regarding their measurement and evaluation experiences in EDS practices stated that they used alternative measurement and evaluation tools. In addition, it was determined that among the 
limitations experienced by the participants in measurement and evaluation, time was a priority. Most of the participants suggested that "Training and Information" should be done about EDS practices in order to increase efficiency. It was determined that almost all of the participants benefited from the mathematics discipline in terms of their experiences of benefiting from other disciplines in EDS practices. The lack of contact with other course teachers stands out among the problems that teachers have stated in this subject.

One of the prominent findings regarding the 3D Modeling used during the practices within the scope of EDS is that all of the participants have awareness of 3D Modeling. One of the striking findings regarding problem situations related to this subject is that all of the participants that the lack of technological tools prevented the 3D modeling studies. About how the physical structure of the school and classrooms affects EDS practices, it is among the opinions of the participants that these structures prevent observation and design. In addition, several suggestions made by the participants on this subject are among the other findings of the research. It is among the prominent positive opinions about the experiences during the teaching of the attainments including EDS practices in the distance education process, that the search for distance education has led the participants to contact a relationship with the technology discipline. The view that participation in distance education activities is limited in EDS practices stands out among the limitations expressed by the participants. Uncontrolled parent intervention in EDS practices has been stated as a negative situation. Performing EDS activities synchronously and asynchronously was determined as the suggestion presented on this subject.

\section{Discussion and Conclusion}

When the opinions of the participants are examined, it can be said that almost all of the participants have experience about EDS. In a study conducted in the year when the 2018 science course curriculum was first implemented, it was concluded that the majority of teachers did not have information about EDS (Koç \& Kayacan, 2018). In this sense, it can be said that the data obtained from the current research brings innovation in terms of literature.

According to the participants; deepening is important in the engineering concept; however, the limitations in the attainments do not allow the subject to be deepened. As a result of the examinations made, for example; In the attainment of $8^{\text {th }}$ Grade Science Course described as "F.8.5.1.2: Designs a mechanism that will provide ease of work in daily life by 
using simple machines", a limitation was observed as "ç: Mathematical connection is not entered" (Ministry of National Education [MoNE], 2018). Lack of guidance for any concrete data and explanations about technology and mathematical process can be seen as a problem in terms of consistency in this regard. The expressions "Mathematical connection is not entered" and "Mathematical relation is not given" in the attainment descriptions reflect this situation (Bahar, Yener, Yılmaz, Emen \& Gürer, 2018). Therefore, this situation makes it difficult for Science Teachers to get to know the field of EDS by deepening it in their courses.

When relations with other disciplines are examined in EDS field activities; Participants stated that they mostly related to mathematics discipline in EDS practices. However, they stated that the level of this relationship was quite limited. It can be said that the relation with Visual Arts dimension is limited to the description of some non-technical visual elements. It can be said that a small number of participants related their EDS practices studies with other courses. However, this relationship is not within an interdisciplinary dimension. As a matter of fact, the participants reported that they could not cooperate with other lesson teachers. In the study conducted by Bahar et al. (2018), the situation that the concept of interdisciplinary perspective included in the 2018 science curriculum "Could not be reflected in the content of the course sufficiently" is consistent with this result of the research.

All of the participants in the research reported that they have awareness of 3D modeling and printing. However, the number of participants who stated that they had knowledge about 3D modeling remained at half rate. The number of participants who stated that they used 3D modeling before in his lesson was limited to one person. It can be shown is as the main reason for this limitation that the school and classrooms do not provide sufficient opportunities for 3D modeling. 


\section{Giriş}

Bireyler, toplumlar varoluşlarından beri bir değişim ve dönüşüm içerisinde olmuştur. $\mathrm{Bu}$ değişim ve dönüşümler süreklilik içinde birbirini tetiklemektedir. Değişim ve dönüşümlere öncülük eden en önemli faktörler; bilimsel ve teknolojik alanlardaki gelişmelerdir (Brown, 2015; Kwon, 2017). Bu gelişmeler 20. ile 21. yüzyıl arasında oldukça yoğun yaşanmıştır. Bu süreçte bilim ve teknolojide çok büyük değişimler meydana gelmiş ve bu değişimler 21. yüzyılda da artarak hızlı bir şekilde devam etmektedir. Bilim ve teknolojide, değişim ve gelişimin hızlı yaşandığı zamanlarda toplumlar yeniliklere açık olmak zorundadır. Bu yenilikleri sürdürmek bireyler ve toplumlar için sorumluluktur (Toraman \& Alc1, 2013).

Bilim ve teknolojideki gelişmeler, mühendislik uygulamaları ile doğrudan bir ilişki içinde olup; ülkelerin ekonomik olarak gelişmesine doğrudan etki etmektedir. Meydana gelen bu değişimler nedeniyle bilgi, beceri, nitelik ve yeterliliklerin çağa uygun bir şekilde bireylere kazandırılması gerekir. Bu durum, eğitim sistemlerinin yeniden düzenlenmesini gerekli kılmaktadır (Harari, 2018). Öğrencilere günlük yaşam ile ilgili karşılaştıkları problemlere çözüm bulma yeteneği kazandırılmasında okulun rolü önemlidir (Ürey \& Cerrah-Özsevgeç, 2015). Bu şekilde yetişen bireylerin problem çözme becerisi ve girişimcilik özelliklerine sahip olması gerekir. Aynı zamanda kazandırılan bu özellikler ışığında ülkenin ekonomik problemlerinin çözümüne de katkı sağlamaktadır (Bakırcı \& Kutlu, 2018). Belirtilen özelliklerin okulda kazandırılması öğretim programları aracılığıyla gerçekleşmektedir. Milli Eğitim Bakanlığı (MEB), 2018 Fen Bilimleri Dersi Öğretim Programı'nda (FEPDÖP) bu durumu şu şekilde açıklamıştır: “Bilim ve teknolojide yaşanan hızlı değişim, bireyin ve toplumun değişen ihtiyaçları, öğrenme öğretme teori ve yaklaşımlarındaki yenilik ve gelişmeler bireylerden beklenen rolleri de doğrudan etkilemiştir. Bu değişim bilgiyi üreten, hayatta işlevsel olarak kullanabilen, problem çözebilen, eleştirel düşünen, girişimci, kararl, iletişim becerilerine sahip, empati yapabilen, topluma ve kültüre katkı sağlayan vb. niteliklerdeki bir bireyi tanımlamaktadır" (Milli Eğitim Bakanlığı [MEB], 2018, s.4). Bilgiyi üretmek, bilgiyi araç olarak kullanarak işlevsel hale getirmek ve bu yönüyle karşılaşılan problemleri çözmek, bilim ve teknolojinin gelişimini sağlayan temel basamaklar olarak düşünülebilir.

Teknolojik gelişime katkıda bulunan pek çok disiplin olmasına rağmen, bu gelişime bazı disiplinler daha çok etki etmektedir. Fen bilimleri ve matematik disiplinleri de teknolojik gelişmeyi etkileyen alanlardır (Demirci, 1993). Bu bağlamda her ülke ya da her 
toplum bilim ve teknoloji eğitimine gereken önemi vermeli, dinamizmi sürekli kılmak için bilim ve teknolojideki eğitim kalitesini arttırmalıdır. Bu kaliteyi arttırmak ve sürdürülebilir bir gelişimin olması için de Fen Bilimleri Dersi Öğretim Programı́nın geleceği yakalaması gerekmektedir. Bu bağlamda son yüzyıl içerisinde fen bilimleri eğitiminin kalitesini artırmak için birtakım girişimlerde bulunulmuştur. Değişimlere ayak uydurmak için girişimlerin büyük bölümü öğretim programını güncellemek veya değiştirmek şeklinde olmuştur (Ayas, 1995; Ayas, Çepni \& Akdeniz, 1993). Belirtilen bu ihtiyaçları karşılamak ve bireyleri istenen özellik ve niteliklere sahip kılmak için ülkemizde fen eğitimi adına öğretim programında çeşitli düzenlemeler yapılmıştır.

Milli Eğitim Bakanlığı 2000 yılından başlayarak 2005, 2013 ve 2018 yıllarında fen eğitimi alanındaki öğretim programlarını yenilemiştir. 2005 Fen ve Teknoloji Dersi Öğretim Programı'nın içerdiği değişimler devrim niteliğinde olmuş; programın vizyonu; "Herkes için fen ve teknoloji okuryazarlığı" olmuştur (MEB, 2005). Türk eğitim sisteminin temelini oluşturan pozitivist yaklaşım, yerini başka bir yaklaşıma bırakmıştır. Bu bağlamda pozitivist ya da Newtoncu deterministik öğretim anlayışları yerine yapılandırmacı öğretim anlayışı getirilmiştir (Türk Eğitim Derneği Düşünce Kuruluşu [TEDMEM], 2013). Ardından 2013 yılındaki Fen Bilimleri Dersi Öğretim Programı (FEBDÖP) ile birlikte dersin adı Fen Bilimleri olarak değiştirilmiş ve bu öğretim programı araştırma ve sorgulama yaklaşımına dayalı olmuştur. 2013 FEBDÖP'ün vizyonu “Tüm öğrencileri fen okuryazarı bireyler olarak yetiştirmek" şeklinde belirtilmiştir (MEB, 2013). Öğretim programlarını yenileme sürecinde 2017 yılına gelindiğinde MEB birçok dersin öğretim programını güncellemiş bu derslerin içinde Fen Bilimleri dersi de yer almıştır. Değişimler kapsamında 2017 Fen Bilimleri Dersi Taslak Öğretim Programı yayınlanmış, program ile ilgili gelen eleştiri ve görüşlerin paralelinde 2018 yılında program son halini almıştır. 2018 FEPDÖP’te alanına özgü bilimsel süreç becerileri ile yaşam becerilerine ilave olarak ilk defa Mühendislik ve Tasarım Becerileri (MTB) alanı yer almıştır.

Milli Eğitim Bakanlığı'na göre MTB, Fen Bilimleri dersi ile matematik, teknoloji ve mühendislik alanlarını sistematik ve bir bütün haline getirmektedir. MTB alanı öğrencileri, problemlere disiplinler arası bir boyut ile yaklaşmaya ve buluş yapmaya teşvik etmektedir. Aynı zamanda bu alan öğrencileri inovatif bir sürece yönlendirmektedir. Böylece derste öğrenilen bilgi ve becerilerin somutlaştırılması ve aktif olarak kullanılması ile öğrencilerin ürün oluşturma sürecine katkı sağlanacaktır. Aynı zamanda MTB alanı öğrencilerin 
tasarladıkları ürünlere ekonomik anlamda nasıl bir katma değer kazandırılabileceklerine ilişkin bir bakış geliştirmelerini amaçlamaktadır (MEB, 2018). Hedefler analiz edildiğinde MTB alanının disiplinler arası anlayıştan geldiği ve Fen-Teknoloji-Mühendislik-Matematik (FeTeMM) yaklaşımına dair öğeleri içerdiği söylenebilir. Bu öğelerden özellikle mühendislik kavramının ilk defa öğretim programında baskın bir şekilde yer alması, Fen Bilimleri dersini okutan öğretmenlerin ilk defa karşılaştığı bir durum olmuştur. Bu açıdan düşünüldüğünde yalnızca öğretim programının güncellenmesinin yanı sıra eğitim sisteminde de bir değişimin söz konusu olduğu söylenebilir.

Toplumlar sosyal, politik, kültürel ve ekonomik olarak gelişmelidir. Bu gelişimi sağlayan en önemli unsur eğitim sistemidir. Eğitim sistemini oluşturan unsurlar ise öğrenci, öğretmen ve öğretim programlarıdır (Gözütok, 2003, s. 607). Bu unsurlardan etkileşim içinde olanlar öğretmen ve öğrencidir. Eğitim sistemini oluşturan bu üç ana unsurda öğretmen; öğretim programı ile öğrenci arasındaki köprüyü kuran unsurdur. Öğretim programının daha nitelikli ve daha etkili bir şekilde uygulanmasının büyük ölçüde öğretmene bağlı olduğu söylenebilir.

Bu araştırma kapsamında, 2018 FEPDÖP içeriğinde yer alan MTB alanı hakkında öğretmenlerin görüşleri ile ilgili literatür taraması yapılmıştır. Literatür incelendiğinde öğretim programları ile ilgili çalışmaların son yıllarda arttığı görülmüştür. Özellikle 2017 yılından sonra 2018 FEBDÖP ile MTB alanının yer alması öğretim programına olan ilgiyi artırmıştır. Literatür taramasında elde edilen bulguya göre 2018 Öğretim Programı'nda yer alan MTB konusunda yapılan çalışmaların oldukça sınırlı olduğu söylenebilir (Bahar, Yener, Y1lmaz, Emen \& Gürer, 2018; Koç \& Kayacan, 2018; Özcan \& Düzgünoğlu, 2017; Saraç \& Yıldırım, 2019). Bu çalışmaların birinde; Saraç ve Yıldırım (2019) yaptıkları araştırmada ortaya şöyle bir sonuç çıkmıştır: Öğretmenler, programı uygulama sürecinde bazı zorluklarla karşılaştıklarını belirtmişlerdir. Belirtilen bu zorlukların açığa çıkarılması ve programın uygulanması sırasında öğretmenlerin yaşadığı problemlerin belirlenmesi gerekli hale gelmiştir. Dolayısıyla öğretim programının uygulanması sırasında yaşanan sorunların açığa çıkarılması ve bu bağlamda öğretmenlerin görüşlerinin alınmasını gerekli kılmıştır.

Öğretmenlerin, MTB uygulamaları sırasında karşılaştıkları problemleri inceleyen çalışmalar oldukça sınırlı olduğu için bu konuda araştırmaların yapılması ve alan yazındaki eksikliğin giderilmesi gereklilik arz etmiştir. Dolayısıyla MTB kapsamındaki deneyimler bağlamında öğretmen görüşlerinin alınması ihtiyacı doğmuştur. Araştırmada Fen Bilimleri 
öğretmenlerinin MTB uygulamalarında karşılaştıkları sorunların ayrı başlıklar altında belirlenmesi ve bu sorunlara ilişkin çözüm önerilerinin oluşturulması amaçlanmıştır. Aynı zamanda araştırma sonuçlarının bu konu üzerinde yapılacak bilimsel çalışmalara 1şık tutması ve öğretim programında yapılacak güncellemelerde katkı oluşturması beklenmektedir.

\section{Yöntem}

\section{Araştırma Modeli}

Araştırma, Fen Bilimleri öğretmenlerinin görüşleri kapsamında 2018 FEBDÖP içerisinde yer alan MTB uygulamaları sırasında karşılaşılan sorunların belirlenmesini ve bu sorunlara kaynak olan nedenlerin derinlemesine ortaya koyulmasını içermektedir. Dolayısıyla bu çalışmada, nitel araştırma yöntemlerinden durum çalışması deseni kullanılmıştır (Cresswell, 2012). Durum çalışması deseni 'neden', 'nasıl' gibi sorular üzerinden bir olgu ya da olayı bütünsel olarak derinlemesine inceleme olanağı sunmaktadır (Çepni, 2018).

\section{Katılimcilar}

Araştırma 2020-2021 eğitim-öğretim yılında Türkiye'nin Güneydoğu Anadolu Bölgesi'nde yer alan Mardin ilinde yapılmıştır. Araştırma kapsamında yapılan katılımcı seçimi evreni temsil etmemektedir. Amaçsal örneklemede küçük bir örneklem aracılığıyla durumun derinlemesine inceleme olanağı bulunmaktadır. Bundan dolayı katılımcı seçiminin amaçsal örnekleme ile seçilmesi uygun görülmüştür (Çepni, 2018). Katılımcılar, ortaokulda Fen Bilimleri öğretmeni olarak görev yapmakta olan ve dersi aktif olarak okutan öğretmenler arasından seçilmiştir. Araştırmada etik ilkeler gözetilmiş; bu nedenle öğretmenlerin isimleri kullanılmamıştır. Öğretmenler, $\ddot{O}_{1}, \ddot{O}_{2}, \ddot{O}_{3} \ldots \ddot{O ̈}_{10}$ şeklinde kodlanmıştır. Katılımcılar ile ilgili detaylar Tablo 1'de gösterilmiştir.

Tablo 1. Katılımclara ait demografik bilgiler

\begin{tabular}{llcl}
\hline Katılımcı & Cinsiyet & Mesleki Deneyim (Yıl) & Eğitim Düzeyi \\
\hline$\ddot{O}_{1}$ & Erkek & 12 & Yüksek Lisans \\
\hline$\ddot{O}_{2}$ & Kadın & 2 & Yüksek Lisans \\
\hline$\ddot{O}_{3}$ & Kadın & 5 & Lisans \\
\hline$\ddot{O}_{4}$ & Erkek & 11 & Lisans \\
\hline$\ddot{O}_{5}$ & Kadın & 5 & Yüksek Lisans \\
\hline$\ddot{O}_{6}$ & Erkek & 20 & Lisans \\
\hline$\ddot{O}_{7}$ & Kadın & 7 & Yüksek Lisans \\
\hline
\end{tabular}


Bakırcı \& Kaplan

\begin{tabular}{llcl}
\hline$\ddot{O ̈}_{8}$ & Kadın & 7 & Lisans \\
\hline$\ddot{O ̈}_{9}$ & Erkek & 14 & Lisans \\
\hline$\ddot{O ̈}_{10}$ & Kadın & 9 & Lisans \\
\hline
\end{tabular}

Katılımcılar, 6 kadın ve 4 erkek öğretmenden oluşmaktadır. Katılımcıların mesleki deneyim süreleri 2 ile 20 yıl arasında değişmektedir. Yüksek lisans düzeyinde 4 katılımcı yer alırken 6 katılımcı ise lisans mezunudur.

Veri Toplama Aracı

Araştırmada veri toplama aracı olarak yarı yapılandırılmış mülakat formu kullanılmıştır. Araştırmayı oluşturan mülakat soruları başlangıçta 10 soru olarak belirlenmiştir. Hazırlanan sorular Nitel Veri Analizi dersini okutmakta olan bir öğretim üyesi ile bu dersi alan üç araştırmacıya inceletilmiştir. İncelemeler sonucunda alınan öneriler doğrultusunda mülakat sorularındaki yapılan değişiklikler şunlardır: "2018 Fen Bilimleri Öğretim programında yer alan MTB uygulamalarında dersin konu/kazanımları sizi nasıl yönlendiriyor? Bu konuda ne tür problemler yaşamaktasınız?" sorusu; MTB uygulamalarında dersin konu/kazanımları sizi nasıl yönlendiriyor? şeklinde düzeltilmiştir. Bir diğer soru olan "2018 Fen Bilimleri Öğretim programında yer alan MTB uygulamalarında programdaki konu ve kazanımlardaki sinırlamalar ne tür olumsuz etkilere neden olmaktadır. Nasıl etkilemektedir." sorusu ise başka bir soru ile benzerlik taşıdığı için mülakat formundan çıkarılmıştır. Aynı zamanda diğer sorulardaki bazı uzun ifadeler anlam bütünlügünü bozmayacak şekilde kısaltılmış ve sadeleştirilmiştir. Yapılan değişiklikler sonucunda araştırma, görüşme formunda yer alan 7 soru ile gerçekleştirilmiştir. Covid-2019 pandemisi nedeniyle hastalığın bulaşma riskini engellemek için araştırma verilerinin toplanması, mülakat formundaki sorulara ilişkin uzaktan görüşme yolu ile alınan ses kayıtları ile gerçekleştirilmiştir. Ortalama görüşme süreleri 30-35 dakika sürmüştür. Mülakat formunda yer alan sorular Ek-1 ‘de sunulmuştur.

\section{Verilerin Analizi}

Araştırmada verilerin analizi, katılımcıların görüşlerini derinlemesine ve doğrudan ifade edebilmesi, katılımcılardan elde edilen verilerin derinleştirilerek incelenebilmesi için betimsel ve içerik analizi yöntemleri kullanılmıştır. Betimsel analizde bulguların düzeltilmesi, yorumlanması için doğrudan alıntılara sıkça yer verilir ve katılımcı görüşleri çarpıcı bir şekilde yansıtılır. Betimsel yaklaşıma ek olarak içerik analizi kullanılma sebebi ise verilerin derinlemesine işlenmesi, tüm ayrıntıları ile detaylandırılması ve kavram ile 
temaların ortaya çıkarılmasının mümkün olmasıdır (Çepni, 2018). Veriler ses kayıtları ile alınmış ardından yazı formatına dönüştürülmüştür. Hata olasılığını en aza indirmek için her katılımcıya ait yazılı görüşler katılımcıya sunulmuş ve katılımcının onayı alınmıştır. Ardından araştırma verileri birbirinden bağımsız iki farklı araştırmacı ve bir uzman tarafından analiz edilmiştir. Araştırmacılardan ikisi Nitel Veri Analizi dersini almış, diğeri ise bu dersi okutan bir uzmandan oluşmaktadır. Araştırmada deneyimli uzmanların yer alması, araştırmanın güvenirliğini olumlu etkilediği söylenebilir.

Araştırmacılar tarafından kod ve temalar çıkarılmıştır. Ardından görüş birliğine varılan ve varılamayan noktaların tespit edilmesi için araştırmacılar toplanmıştır. Analize son şeklinin verilmesinde Miles ve Huberman'ın (1994) geliştirdiği formül kullanılmıştır. Bu formül, Güvenirlik = Görüş Birliği / (Görüş Birliği + Görüş Ayrılığı) şeklindedir. Bu formül aracılığıyla veriler analiz edilmiştir. Verilerin analizi sonucunda araştırmacılar arasındaki uyum güvenirliği katsayısı 0,87 olarak bulunmuştur (Miles \& Huberman 1994). Analiz sonucunda elde edilen kod ve temalar tablolara dönüştürülmüştür. Tablo şeklinde verilmesi okuyucuların okuması ve yorumlamasını kolaylaştırmaktadır.

\section{Araştırmanın Geçerliliği ve Güvenirliliği}

Nicel araştırmalarda geçerlik ve güvenirlik ifadeleri kullanılırken; nitel araştırmalarda daha çok inanılırlık, sonuçların doğruluğu ve araştırmacının yetkinliği gibi ifadelerden yararlanılır. Dolayısıyla nitel araştırmaların geçerliliği ve güvenirliği; inanılırlık, tutarlılık, genellenebilirlik ve doğrulanabilirlik kavramları ile sağlanmaktadır (Krefting, 1991). Çalışmanın inanırlılığı için veriler ve analizler araştırılan kişilere sunulmuştur. Ses kayıtları alınarak yazı formuna dönüştürülmüştür. Verilerin değerlendirilmesinde farklı araştırmacının da görüşleri alınmıştır. Güvenirliğini artırmak için katılımcılar gönüllü öğretmenlerden seçilmiş olup verilerin analiz edilmesinde birden fazla analiz kullanılmıştır. Etik kurallar gereği katılımcı isimleri kodlanmıştır. Ses kayıtları silinmiştir.

\section{Bulgular}

Araştırmaya katılan Fen Bilimleri öğretmenlerinin mülakat formunda yer alan sorulara verdikleri yanıtlar soru bazında incelenmiş ve okuyuculara sunulmuştur.

Öğretmenlerin mülakat formunun birinci sorusuna verdikleri cevaplardan oluşturulan tema ve kodlar Tablo 2'de verilmiştir. 
Tablo 2. Fen Bilimleri öğretmenlerinin “MTB hakkında ne düşünüyorsunuz?" sorusuna verdikleri cevaplardan oluşturulan tema ve kodlar

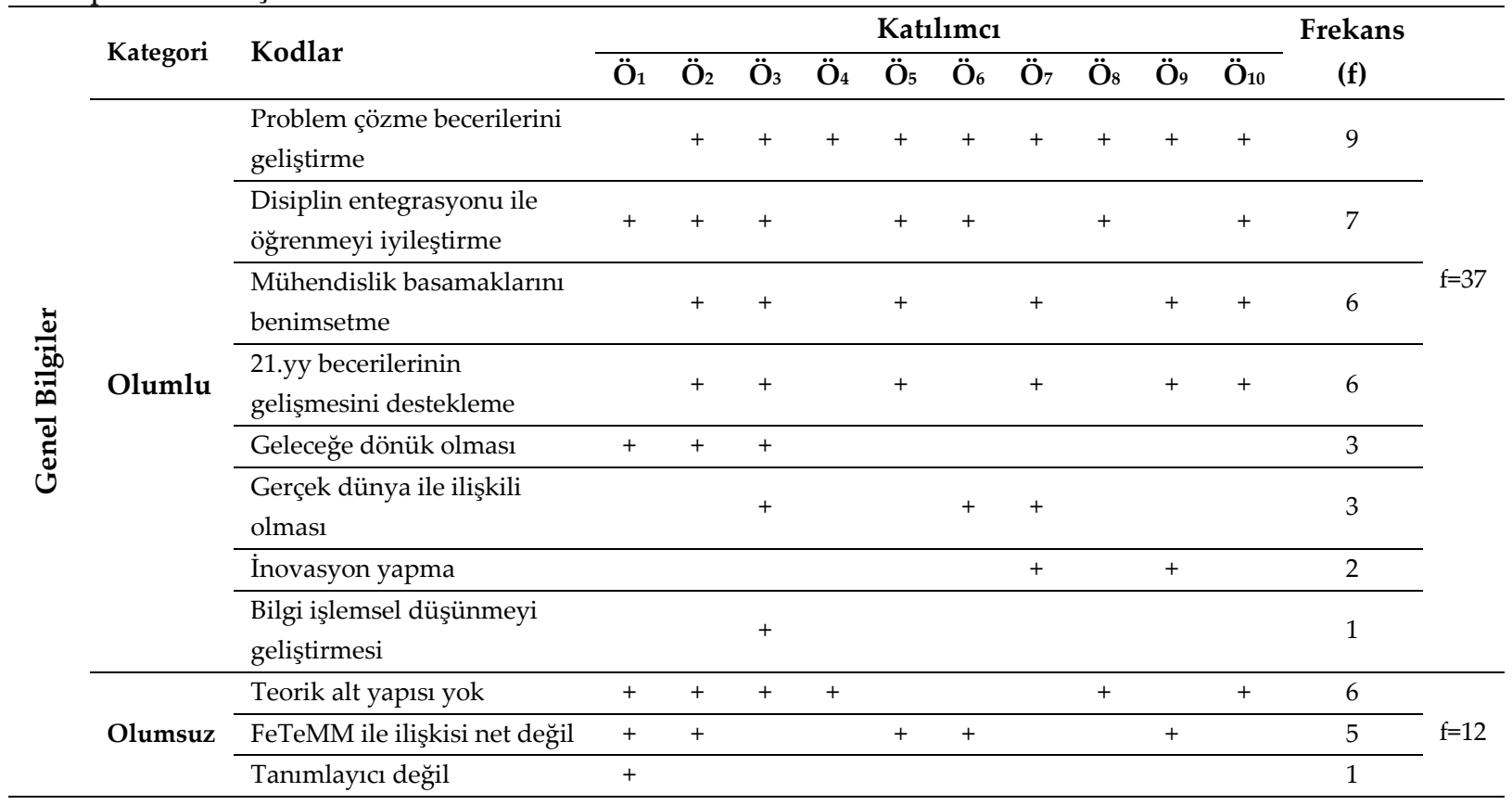

Tablo 2 incelendiğinde MTB uygulamalarını en az iki yıl deneyimleyen Fen Bilimleri öğretmenlerinin, $\mathrm{MTB}^{\prime}$ ye yönelik görüşlerini olumlu ve olumsuz nitelikler ile beyan ettikleri görülmektedir. Öğretmenlerin büyük bir bölümü (f=9) MTB'nin problem çözme becerisini geliştirdiğini beyan etmiştir. Bu görüşü $\mathrm{MTB}^{\prime}$ nin disiplin entegrasyonu ile öğrenmeyi iyileştirdiği görüşü ( $\mathrm{f}=7$ ) takip etmiştir.

Mühendislik konuların uygularken çocukların problem çözme becerisi geliştirdiğini gördüm. Aynı zamanda konular gerçek yaşam ile ilişkili ve diğer disiplinlerle ortak iş yapabilme öğrenmeyi daha anlamlı kllıyor (Ö6).

Gerçek yaşamı dersimize indirgememizi sağhlyor. İnovasyon yapma becerisini geliştiriyor. Eleştirel düşünme, yaratıcllı, iş birliği gibi 21. yüzyıl becerilerinin gelişmesini desteklediğini söyleyebilirim (Ö7).

Katılımcılar olumsuz görüş olarak, MTB' nin program içerisinde teorik altyapısının olmadığını ( $\mathrm{f}=6$ ) ve FeTeMM ile ilişkisinin net olmadığını $(\mathrm{f}=5)$ ifade etmişlerdir.

MTB'nin FeTeMM eğitiminden kök almış fakat teorik altyapısı tam olarak doldurulmadan uyarlanmış bir kavram olduğunu düşünüyorum. Uluslararası literatüre baktığımızda bu kavramların bu haliyle kullanılmadığını, bu kavramın altyapısının da öğretmenlerle hiçbir yerde paylaşılmadığını düşünüyorum (Ö1).

Öğretim programına baktığımızda MTB'nin FeTeMM'den esinlenerek programa entegre edildiğini fakat kavramsal olarak yeterince açıklanmadığını düşünmekteyim. Bu nedenle uygulanması konusunda sorunlar görüyorum (Ö2). 
Katılımcıların mülakat formunun ikinci sorusuna verdikleri cevaplardan oluşturulan tema ve kodlar Tablo 3'te verilmiştir.

Tablo 3. Fen Bilimleri öğretmenlerinin "MTB uygulamalarında dersin konu/kazanımları sizi nasıl yönlendiriyor?" sorusuna verdikleri cevaplardan oluşturulan tema ve kodlar

\begin{tabular}{|c|c|c|c|c|c|c|c|c|c|c|c|c|c|}
\hline \multirow{2}{*}{\multicolumn{2}{|c|}{ Kategori }} & \multirow{2}{*}{ Kodlar } & \multicolumn{10}{|c|}{ Katılımcı } & \multirow{2}{*}{$\begin{array}{c}\text { Frekans } \\
\text { (f) }\end{array}$} \\
\hline & & & $\ddot{O}_{1}$ & $\ddot{\mathrm{O}}_{2}$ & $\ddot{\mathrm{O}}_{3}$ & $\ddot{\mathrm{O}}_{4}$ & $\ddot{O O}_{5}$ & $\ddot{O ̈}_{6}$ & $\ddot{O}_{7}$ & $\ddot{O}_{8}$ & Ö$_{9}$ & $\ddot{O ̈}_{10}$ & \\
\hline \multirow{8}{*}{ 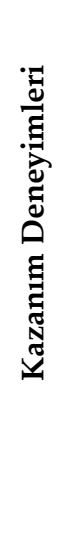 } & \multirow{3}{*}{ Olumlu } & Yönlendirici & & + & + & + & + & + & + & + & & & 7 \\
\hline & & Açılayıcı & & + & + & + & & + & + & & + & & 6 \\
\hline & & Uyumlu & & & & & + & & + & & & + & 3 \\
\hline & \multirow{3}{*}{ Olumsuz } & Sinırlayıcı & + & + & + & + & & & & + & & + & 6 \\
\hline & & Tutarsız & + & + & & + & & + & & + & + & & 5 \\
\hline & & Uyumsuz & + & & & + & & + & & + & & & 3 \\
\hline & \multirow[b]{2}{*}{ Öneriler } & $\begin{array}{l}\text { Kazanımlar yeniden } \\
\text { düzenlenmelidir }\end{array}$ & + & + & & + & & + & & + & + & + & 7 \\
\hline & & $\begin{array}{l}\text { Konular } \\
\text { derinleştirilebilir } \\
\text { olmalıdır }\end{array}$ & + & + & & & & & + & & + & + & 5 \\
\hline
\end{tabular}

Tablo 3 incelendiğinde katılımcıların dersin konu ve kazanımlarının program içeriğinde yer alan 'MTB' alanıyla ilişkisini, kendi deneyimlerini aktararak ifade ettikleri görülmektedir. Katılımcılar dersin içerisinde yer alan kazanımlar hakkında olumlu ve olumsuz görüşler ileri sürerek önerilerde bulunmuşlardır.

Katılımcıların önemli bir bölümü (f=7) kazanımların 'yönlendirici' olduğunu beyan etmiştir. Bu görüşü kazanımların 'açıklayıcı' (f=6) olduğu görüşü takip etmiştir.

Bazen bu uygulamalar bizi sinırlandırırken, bazen de mevcut problem durumlarına göre konuya yönelik yönlendirmeler olmakta, aynı zamanda açıklayıcı olduklarını düşünüyorum (Ö4).

Kazanımlar puzzle parçaları gibi uyumlu. Kazanımlarda tasarlar, geliştirir gibi yüklemleri gördüğ̈̈̈mde mühendislik temalı olduklarını anlıyorum (Ö5).

Kazanım cümlelerinin sonlarında proje tasarlar, proje geliştirir, ürettiği fikirleri tartışır vb. şeklinde anahtar kelimeler yer alıyor. Bu kazanımlara bakarak yönlendirme yapıyoruz (Ö8)

Katılımcılar olumsuz görüş olarak $(\mathrm{f}=6)$ kazanımların sınırlayıcı olduğunu belirtmişlerdir. Aynı zamanda kazanımların programın içerisinde yer alan MTB alanıyla tutarsızlık oluşturduğunu ( $\mathrm{f}=5)$ dile getirmiştir.

Bazı kazanımların sınırlı olması programın tutarsızlı̆̆ını gösteriyor. Örneğin basınç konusunu işlememizi basınç konusu ile ilgili bir ürün tasarlanmasını istiyor. Yani öğrencinin mühendislik ve tasarım sürecini kullanmasını istiyor. Fakat diğer yandan kazanımda hiçbir şekilde matematiksel bă̆ıntı kullanılmaması gerektiği şeklinde sınırlama koyuyor (Ö1). 
Kazanımların programın ana temasıyla uyuşmadığını düşünüyorum. Sınırlama çok fazla. Birçok örnek verebilirim. Öğretim programı FeTeMM yaklaşımına göre hazırlanmaktan çok sadece teknoloji ve tasarım ile ilişkili gibi. Uyumsuz olduğunu söyleyebilirim (Ö8).

Kazanımların yer yer koyduğu sınırlamalar ise bu konuda bir sorun oluşturmaktadır. Örneğin çocuk basit makineler ile ilgili bir araç tasarlayacak ama bu konuda hiçbir matematiksel işlem yapmaması gerekir. Bu durum işin doğasına aykırıdır (Ö2).

Mesela öğretim programına baktığımızda fen, teknoloji, mühendislik ve matematĭğe atıfta bulunmasına rağmen, kazanımlardaki sınırlamalar bu durumla uyuşmuyor (Ö6).

Katılımcıların büyük bir bölümü (f=7) öneri olarak kazanımların disiplinler arası çalışmayı sınırlandırmayacak şekilde yeniden düzenlenmesi gerektiğini önermişlerdir. Katılımcıların yarısı da $(\mathrm{f}=5)$ mühendislik uygulaması için konuların derinleştirilebilir nitelikte verilmesi gerektiğini önermiştir.

Kazanımlar mühendislik becerilerinin kazandırılmasını sınırlamayacak şekilde yeniden ele alınmalıdır (Ö2).

Kazanımlara bağlı kalmak açıkçası beni ve öğrencilerimi sınırladığını düşünüyorum ve kazanımların tekrardan gözden geçirilmesi lazım bazı sınırlamalar amaçla örtüşmüyor. Kazanımlar düzeltilmelidir. Hatta konular daha içerik olarak derinleştirilebilir şekilde verilebilmelidir (Ö10).

Katılımcıların mülakat formunun üçüncü sorusuna verdikleri cevaplardan oluşturulan tema ve kodlar Tablo 4'de verilmiştir.

Tablo 4. Fen Bilimleri öğretmenlerinin "MTB uygulamalarında ölçme ve değerlendirme deneyimleriniz nelerdir?" sorusuna verdikleri cevaplardan oluşturulan tema ve kodlar

\begin{tabular}{|c|c|c|c|c|c|c|c|c|c|c|c|c|c|}
\hline & \multirow{2}{*}{ Kategori } & \multirow{2}{*}{ Kodlar } & \multicolumn{10}{|c|}{ Katılımci } & \multirow{2}{*}{$\begin{array}{c}\text { Frekan } \\
\text { s (f) }\end{array}$} \\
\hline & & & $\ddot{O}_{1}$ & $\ddot{\mathrm{O}}_{2}$ & $\ddot{\mathrm{O}}_{3}$ & $\ddot{\mathrm{O}}_{4}$ & $\ddot{\mathrm{O}}_{5}$ & $\ddot{O ̈}_{6}$ & $\ddot{\mathrm{O}}_{7}$ & $\ddot{O ̈}_{8}$ & $\ddot{O ̈}_{9}$ & $\ddot{O}_{10}$ & \\
\hline \multirow{11}{*}{ 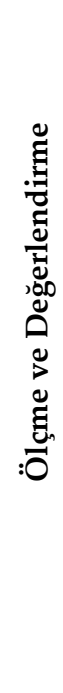 } & \multirow{4}{*}{ Deneyim } & $\begin{array}{l}\text { Alternatif ölçme ve } \\
\text { değerlendirme araçları }\end{array}$ & & + & + & & + & + & + & + & + & + & 8 \\
\hline & & Süreç odaklı & & + & + & & + & + & + & & + & + & 7 \\
\hline & & Tasarım şeması odaklı & & & & & & & + & & & + & 2 \\
\hline & & Sonuç/ürün odaklı & & & & & & & & & + & & 1 \\
\hline & \multirow{5}{*}{ Sinurlılık } & Zaman & + & + & + & + & & + & & + & & + & 7 \\
\hline & & Yazilı sinav & + & + & + & + & + & & + & & + & & 6 \\
\hline & & Motivasyon/isteksizlik & + & + & & + & & + & & + & & & 5 \\
\hline & & Sinav kayg1s1 & + & + & & & & & & & & & 2 \\
\hline & & Bilgi eksikliği & + & & & & & & & & & & 1 \\
\hline & \multirow[b]{2}{*}{ Öneriler } & Eğitim ve bilgilendirme & + & + & + & + & & + & & + & + & + & 8 \\
\hline & & $\begin{array}{l}\text { Proje çalışmalarının } \\
\text { dönem sonu puanına } \\
\text { etkisinin arttırılması }\end{array}$ & & + & + & + & & & & & & + & 4 \\
\hline
\end{tabular}


Tablo 4'te katılımcıların 'MTB' uygulamalarındaki ölçme ve değerlendirme deneyimleri ile ilgili görüşleri yer almaktadır. Katılımcıların çoğu (f=8) ‘Alternatif Ölçme ve Değerlendirme Araçlarını' kullandıklarını belirtmişlerdir. Buna ek olarak 'Süreç Odaklı' değerlendirmenin katılımcıların çoğu (f=7) tarafından kullanıldığı belirlenmiştir.

Süreci notlandırma ile değil, öğrenciye süreçteki uygulamalar hakkında geri dönüt sağlanarak tamamlanmalıdır. Bunların yanında, öğrenci merkezli uygulamalarda kullanılan yapılandırılmış grid, tanılayıcı dallanmış ă̆aç, kavram haritaları gibi teknikler de yine ürünü ya da sonucu değil, süreci merkeze alarak uyarlanabilir (Ö3).

Öğrencileri değerlendirmede bu başliklara verilen yanttarn alternatif ölçme ve değerlendirmeyi sağlamak amacıyla kullanıyorum (Ö7).

Süreç ve ürün odaklı ölçme ve değerlendirme yaklaşımlarını kullanmaya özen gösteririm. Öğrencilerden portfolyo oluşturmalarını, ürünlerinin son hali ile ilgili rapor hazırlamaların ve sinıfa sunmaların beklerim. Bunun sonucunda süreci ve ürünü puanlandırırım (Ö9).

Katılımcılar ölçme ve değerlendirme konusunda çeşitli sınırlılıklarla karşılaştıklarını bildirmişlerdir. Buna göre katılımcıların çoğu (f=7) zaman sorunu yaşadığını belirtmiştir. Bunu yazılı sinavlar $(\mathrm{f}=6)$ ve motivasyon/isteksizlik $(\mathrm{f}=5)$ takip etmiştir.

Kendi deneyimim süreç gereği yalnızca çoktan seçmeli sorularla sınırlı kaldığı için bu becerileri ölçemediğimi belirtebilirim. Zamanın yetersizliği ve merkezi sınav kaygısı da deneyimi engelliyor (Ö1).

En çok zaman sorunu olduğunu düşünüyorum. Dönüm sonu notlarda yazll sınav notlarının çok daha ă̆ırlıkl olması mühendislik kazanımlarının puanlamadaki önemini kısıtlıyor. Çünkü proje ve performans notlarmin etkisi az (Ö4).

Uzun bir süreç ve zahmet gerektirdiği için motivasyonu sağlamak çoğu zaman gǚç oluyor (Ö6).

Yazılı sınavlarda ölçümü ise oldukça zordur. Sinavlar sadece yazılı sinavlardan ibaret olmamahdır. Portfolyo yapalım desem ona da zaman yetmiyor (Ö10).

Katılımcılar yaşadıkları sorunların çözümüne ilişkin önerilerde bulunmuşlardır. Katılımcıların büyük bir bölümü ( $\mathrm{f}=8)$ verimin arttırılması için MTB uygulamaları hakkında 'Eğitim ve Bilgilendirme' yapılması gerektiğini önermiştir. Katılımcıların diğer bir kısmı ise $(\mathrm{f}=4)$, MTB kapsamında yapılan çalışmaların dönem sonu puanına etkisinin yazılı sınavların aşağısında kalması nedeniyle bu durumun gözden geçirilmesini belirtmişlerdir.

Programı hazırlayanlar ya da bu konudaki uzman kişilerin MTB ilgili tüm öğretmenlere bilgi vermesi ve deneyimlerini arttırması gerekir (Ö1).

Bu kazanımları nasıl ölçeceğimiz ile ilgili uzmanların bize eğitim vermesi gerek. Proje notlarının en azından bir sınav kadar etkili olması öğrenciyi güdüleyeceğini düşünüyorum (Ö3). 
Dönüm sonu notlarda yazılı sınav notlarının çok daha ă̆ırlıklı olması mühendislik kazanımlarının puanlamadaki önemini kısıtlıyor. Çünkü proje ve performans notlarının etkisi az (Ö4)

Katılımcıların mülakat formunun dördüncü sorusuna verdikleri cevaplardan oluşturulan tema ve kodlar Tablo 5 'te verilmiştir.

Tablo 5. Fen Bilimleri öğretmenlerinin "MTB uygulamalarında diğer disiplinlerden faydalanma deneyimleriniz nelerdir?" sorusuna verdikleri cevaplardan oluşturulan tema ve kodlar

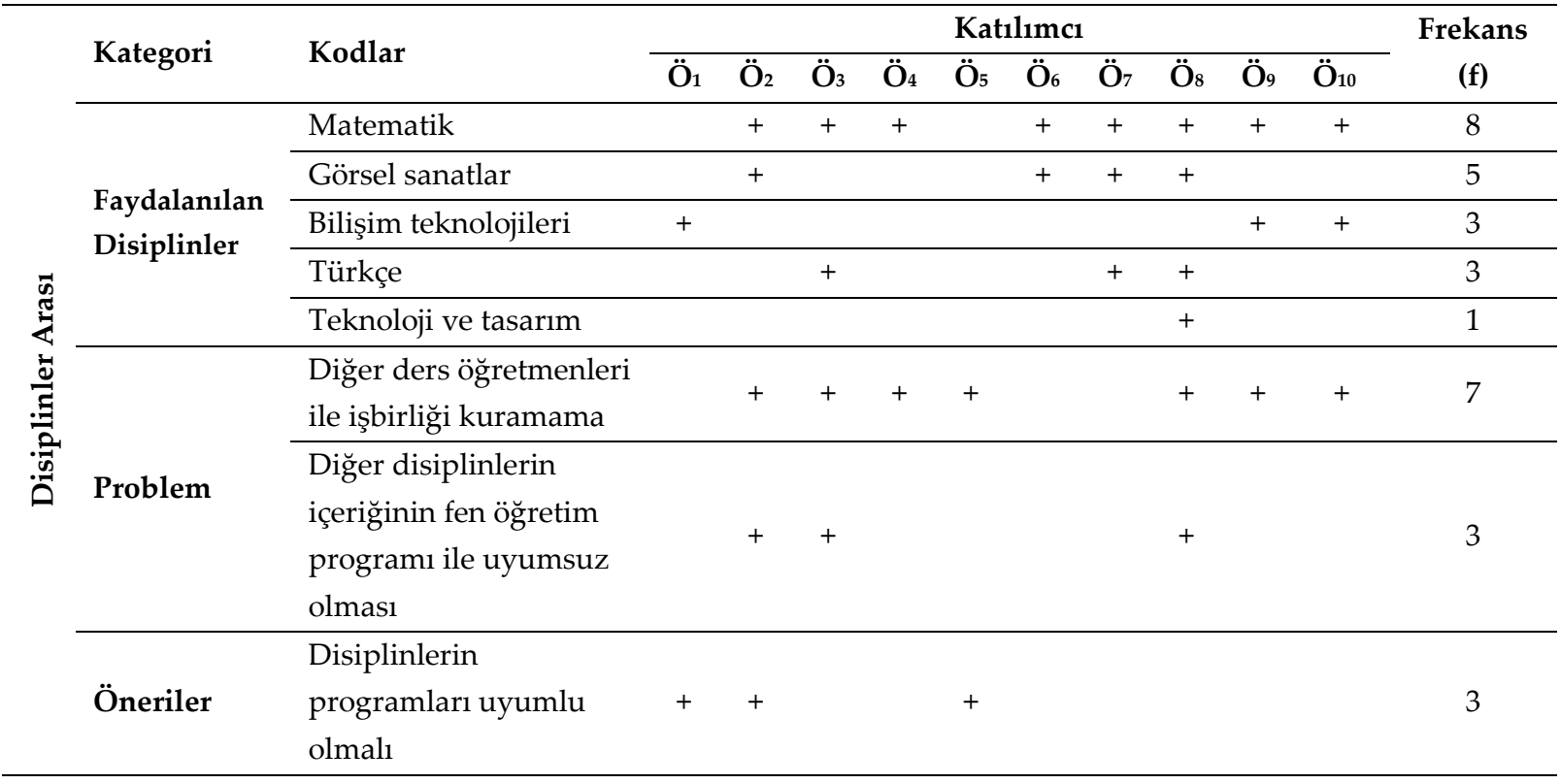

Tablo 5 incelendiğinde katılımcıların tamamına yakınının $(\mathrm{f}=8), \quad$ MTB uygulamalarında matematik disiplininden faydalandıkları görülmektedir. Katılımcılar ( $\mathrm{f}=5)$ ürün oluşturma sırasında estetik kaygıyı da ön planda tuttuklarını bildirmiş ve bu nedenle Görsel Sanatlar disiplini ile ilişki kurduklarını belirtmişlerdir.

Ben geçen sene 5 bu sene de 6. sinfflara devam ettiğim için özellikle matematiği sadece basit hesaplamalar yaparken kullandık. Çoğunlukla da görsel sanatlardan faydalanıyoruz. Görsel sanatlar öğretmeni ile işbirliği yapmak işimizi kolaylaştırıyor (Ö6).

MTB'nin en sık ihtiyaç duyduğum disiplinler Matematik, Görsel Sanatlar, Teknoloji Tasarım ve Türkçe oluyor (Ö8).

Katılımcılar diğer disiplinler ile ilişki kurduklarını bildirmelerine rağmen bu ilişkinin kendi bilgileri ile sınırlı kaldığını (f=7) belirtmişlerdir. Aynı zamanda bazı katılımcılar (f=3), diğer derslere ait öğretim programlarının içerik açısından birbiri ile uyumlu olmaması durumunun, mühendislik çalışmalarını sınırladığını beyan etmiştir.

Tabi tüm bunlarn yaparken kendi bilgilerim ölçüsünde yapabiliyorum. Diğer derslerin öğretmenleri ile iletişim kurarak ya da işbirliği yaparak çalışamıyorum (Ö2). 
Diğer disiplinlerden faydalana bilmek için öncelikle disiplinlere hâkim olmak gerekir. Disiplinleri tanımadan diğer disiplinlerden faydalanamayacağın deneyimledim (Ö5).

Diğer disiplinleri dersimizde kullansak da derslerin içeriklerinin birbirinden kopuk olması ve tamamlayıcı olmaması işbirliğini zorlaştırıyor (Ö6).

Ama ne yazık ki mevcut ortamda mümkün olmamaktadır. Örneğin çocuğun çizgi grafiğini işlemesi gereken bir zamanda fen dersi için söylüyorum. Matematik dersinde o konuyu görmediğini söylüyor. Ya da ondalıkl ölçüm yapacak diyelim bakıyorum matematikte işlememiş. Bu durum çalışma sorunu ortaya koyuyor (Ö8).

Katılımcılar ( $\mathrm{f}=3$ ) öneri olarak MTB disiplinler arası bir çalışma gerektirdiği için diğer disiplinlerin ders programları uyumlu (senkronize) olması gerektiğini belirtmişlerdir.

Farklı disiplinlerin ders programları kopuktur. Her biri ayrı telden çalıyor ve bunları bir biri ile uyumlu olması gerekir. Aksi halde çalı̧malarımız pek de nitelikli olmaz, gelişmez. Orkestra gibi olması gerekir (Ö1).

Mesela keşke derslerin kazanımları aynı anda disiplinler arası çalışma yapacak nitelikte senkronize olsa (Ö2).

Katılımcıların mülakat formunun beşinci sorusuna verdikleri cevaplardan oluşturulan tema ve kodlar Tablo 6'da verilmiştir.

Tablo 6. Fen Bilimleri öğretmenlerinin "MTB kapsamındaki uygulamalar sırasında kullanılan üç boyutlu modelleme (3B Modelleme) hakkında ne düşünüyorsunuz?" sorusuna verdikleri cevaplardan oluşturulan tema ve kodlar

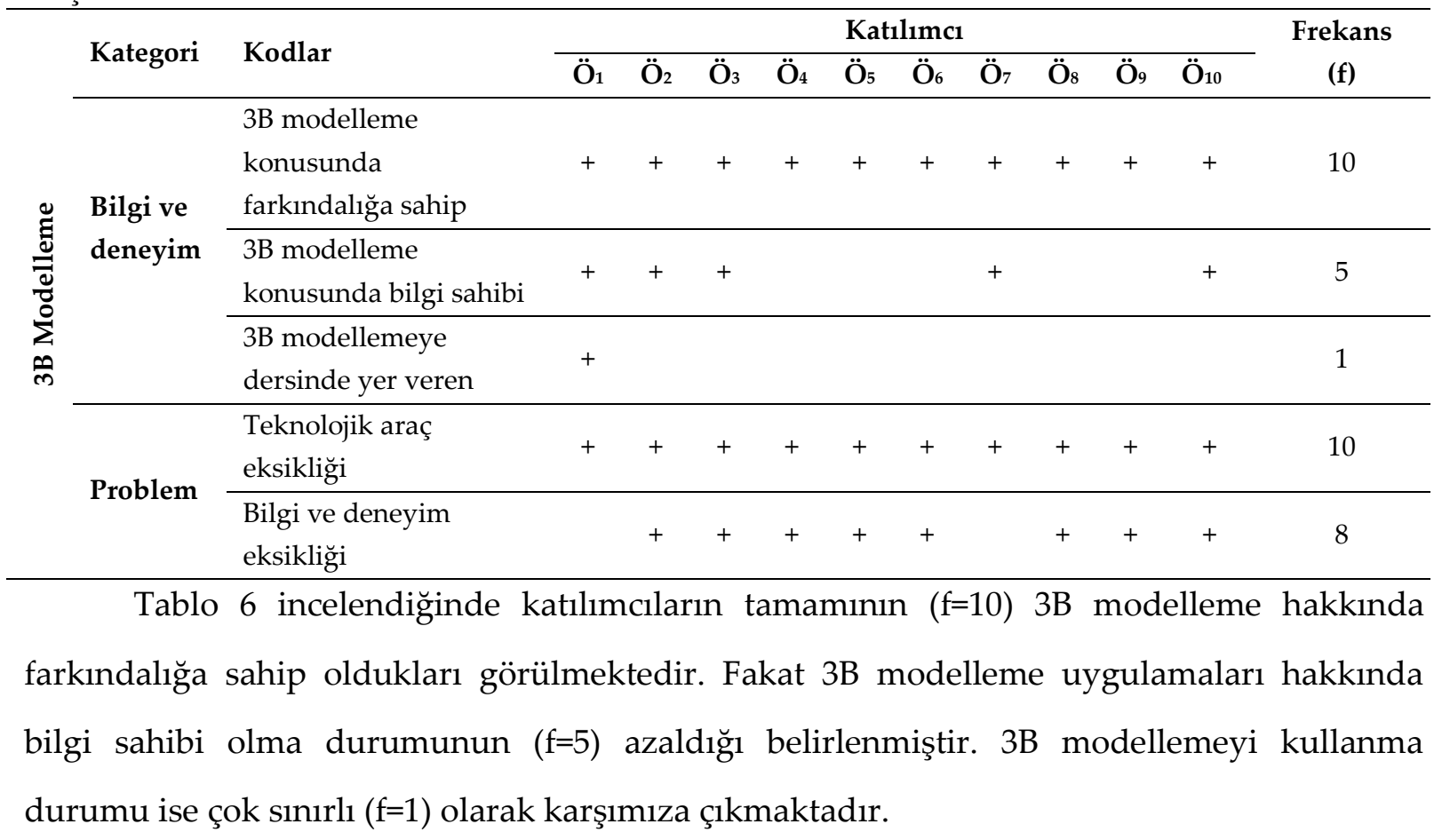


Öğrencilerimize her projede akullarından geçenleri önce ayrnntılarıla modelleyebilsinler diye tinkercad öğreniyorlar, bilişim öğretmenlerinden rica ettim. Çünkü hiçbir zaman teoriyle pratik aynı olmaz, hem belki ihtiyaçları olan bir parça olursa 3B yazıcıdan çıktı alırlar (Ö1).

3B modelleme duyduğum ve tanı olduğum ama ders sürecinde deneyimlemediğim bir uygulama (Ö3).

Bu mühendislik ve tasarım sürecinin en önemli basamă̆ı aslında. Ancak öğretim programını uyguladığım dönemde okulumuzda yeteri kadar bilgisayar olmadığı için modellemeyi kâğıt üzerinde çizim yaparak ve sonra atık malzemelerden oluşturduğumuz modellerle gerçekleştirebildik (Ö7).

Katılımcıların tamamı ( $\mathrm{f}=10)$ teknolojik araç eksiliğinin 3B modelleme çalışmalarını engellediğini, bir problem durumu olarak belirtmişlerdir. MTB uygulamalarındaki 3B modelleme konusunda yaşanan bilgi ve deneyim eksikliği ise katılımcıların tamamına yakını $(\mathrm{f}=8)$ tarafından ifade edilen bir diğer problem durumudur.

Fakat bu konuda çalışma firsatım olmadı. Bilgim de yok zaten. Ama bildiğim şudur mühendislik ve tasarımın bir üst noktaya gelmesi için 3B modelleme şarttır (Ö6).

Üç boyutlu modelleme sayesinde bir cismin herhangi bir yüzeyinin özel bir yazllım aracılığıyla üç boyutlu matematiksel olarak ifade edilebiliyor. Fakat bu konuda bize eğitim verilmediği için, ayn zamanda teknolojik imkânsızlıklar yararlanma konusunda sorun oluşturmaktadır (Ö9).

Katılımcıların mülakat formunun altıncı sorusuna verdikleri cevaplardan oluşturulan tema ve kodlar Tablo 7'de verilmiştir.

Tablo 7. Fen bilimleri öğretmenlerinin “okulun ve sınıfların fiziksel yapısı MTB uygulamalarını nasıl etkilemektedir? Daha etkili uygulanabilmesi için öneriniz nedir?" sorusuna verdikleri cevaplardan oluşturulan tema ve kodlar

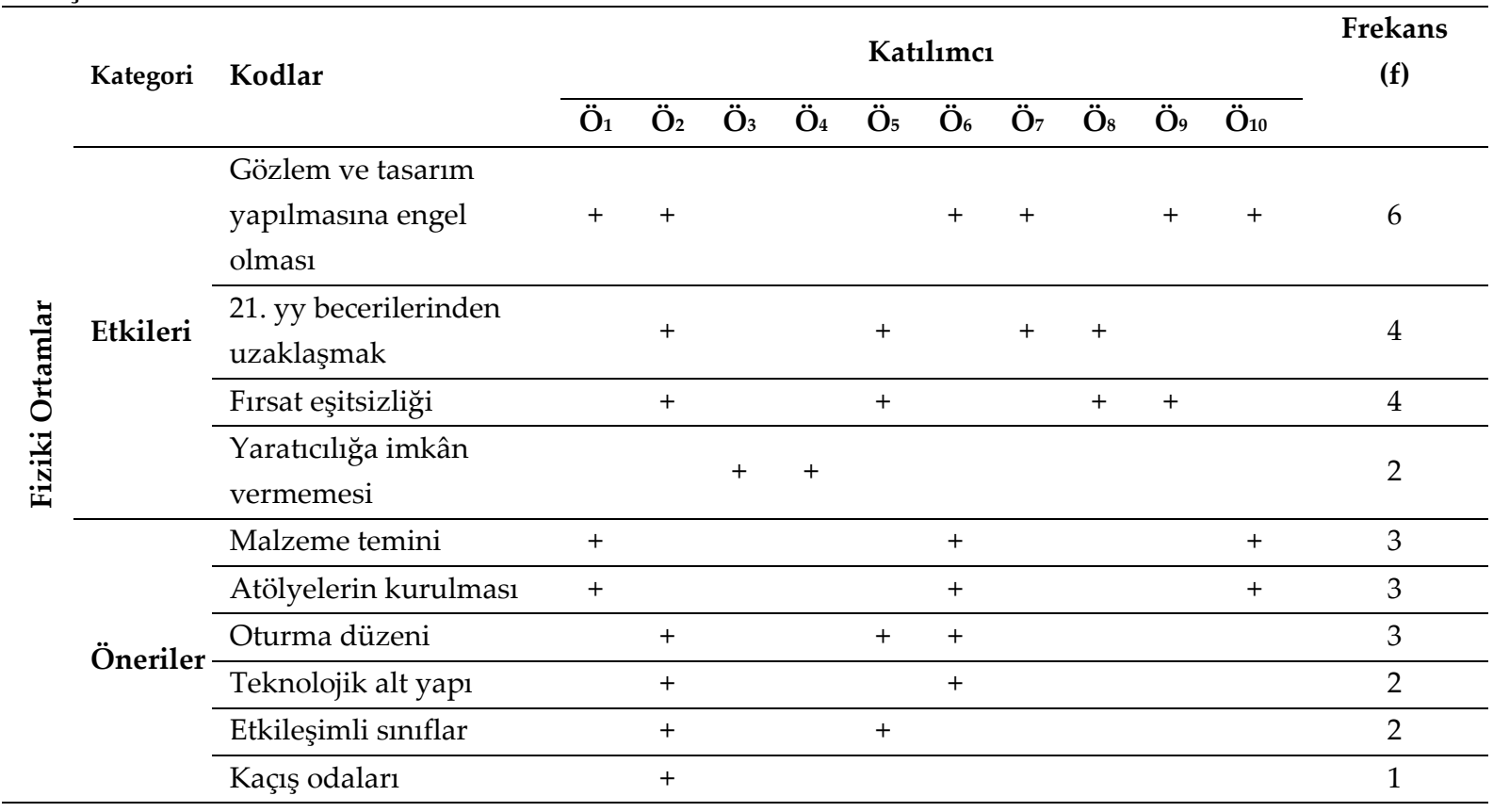


Tablo 7 incelendiğinde katılımcıların sınıf ve okulların fiziksel ortamların olumsuz etkilerini ön plana çıkardığı görülmektedir. Katılımcıların çoğu (f=6) okul ve sınıfların fiziksel yapısının gözlem ve tasarım yapılmasını engellediğini belirtmiştir. Katılımcılar aynı zamanda 21. yy becerilerinden uzaklaştırdığını $(f=4)$, fırsat eşitsizliği oluşturduğunu (f=4) ve yaratıcılığa imkân vermediğini (f=2) bildirmiştir.

Sınıf ortamının da öğrencilerin gözlem yapabilmeleri, tasarımlarını test edebilmeleri için yetersiz olduğunu düşünüyorum. Az da olsa bazı okulların imkânlarının iyi olması firsat eşitsizliğini oluşturmaktadır (Ö2).

Okulların fiziki yapısı kesinlikle hiç uygun değil. Okullar zaten kesinlikle öğrenciler düşünülerek tasarlanmıyor. Mesela geçen sene yaptı̆̆ımız uygulamalarda silikon tabancası kullanmamız gerekiyordu, çocuklar kullanabilmek için yerlere yattılar (Ö6).

Öğretmenler MTB uygulamalarındaki okul ve sınıf ortamlarının olumsuz etkilerine karşı bazı önerilerde bulunmuşlardır. Buna yönelik bazı katılımcılar yaptığı çalışmaların olumlu etkilerinden bahsetmiştir.

Çalıştığım okulda da fiziksel ortamı kendim hazırlama imkânı buldum. Bunları düşünerek de öğrencilerin ihtiyacına yönelik bir ortam hazırlamaya çalı̧sım. STEM atölyemizde bilgisayarlar, çeşitli alet, ahşap atölye malzemeleri, sensörler, robotik ve atık malzemeler, kırtasiye malzemeleri, özel masalar vb. mühendislik çalışmalarını oldukça yükseltiyor (Ö1).

Okulda gerçekleştirdikleri projelerin üretimini yapabilecekleri öğrenme alanları tasarlanmalıdır. Kaçış odaları yapılabilir (Ö2).

Ben her ilçenin etkileşimli deneyler ve proje çalışmalar için gerekli malzemeleri (bilgisayar, 3B Yazıcl, montaj ve tasarım aletleri vs) içeren bir Bilim Merkezi'ne sahip olmasının bu konuda destek olabileceğine inanıyorum. Randevu sistemiyle ilçedeki her okul öğrenci ve öğretmenleri bu imkânlardan yararlanarak çalışmalarını okul dışında da sürdürebilir (Ö8).

Katılımcıların mülakat formunun yedinci sorusuna verdikleri cevaplardan oluşturulan tema ve kodlar Tablo 8' de verilmiştir. 
Tablo 8. Fen bilimleri öğretmenlerinin "uzaktan eğitim sürecinde MTB uygulamalarını içeren kazanımların öğretimi sırasındaki deneyimleriniz nelerdir?" sorusuna verdikleri cevaplardan oluşturulan tema ve kodlar

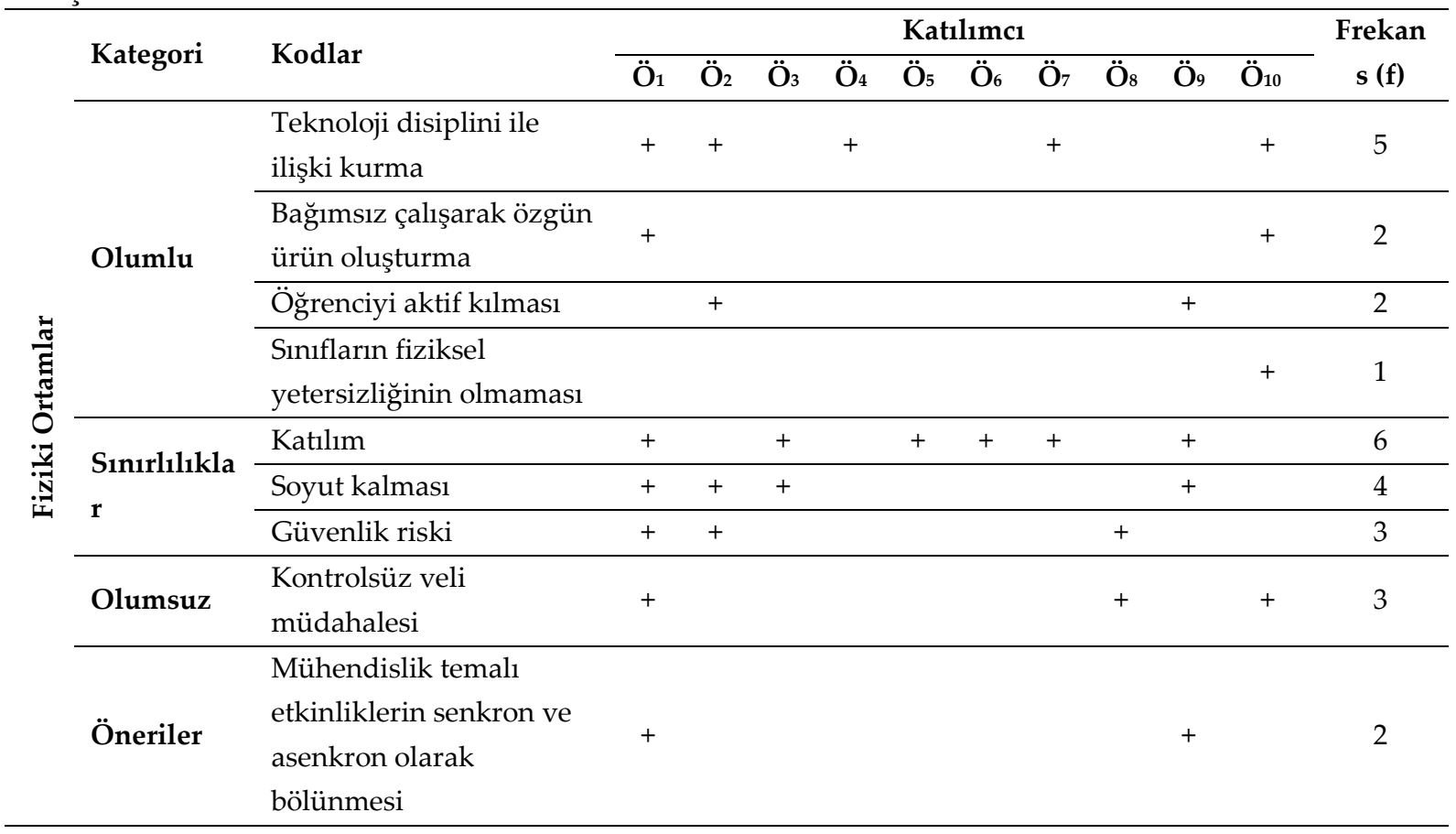

Tablo 8'e göre katılımcılar, MTB uygulamalarını uzaktan eğitim uygulamaları ile deneyim kazandıkları görülmektedir. Uzaktan eğitim arayışlarının katılımcılarda (f=5) teknoloji disiplini ile ilişki kurma noktasında bir gelişime neden olduğu belirtilmiştir. Bazı katılımcılar $(\mathrm{f}=2)$ uzaktan yaptırılan çalışmaların bağımsız çalışma ve özgün ürün oluşturmasına katkı sağladığını belirtmiştir. Diğer olumlu etkiler olarak öğrenciyi aktif kılması ( $\mathrm{f}=2$ ) ve sınıfların fiziksel yetersizliğinin olmaması durumu bir katılımcı tarafından belirtilmiştir.

Öğrencinin kendini rahat hissettiği ortamda çalışmasını gözlemlerini ve araştırmalarını özgürce yapabilmelerini sağlar. Derslerin monoton olarak işlendiği düşünülürse ekran başında aktif olamayan öğrencilerin mühendislik ve tasarım kazanımlarında verilen ödevlerde aktif yer alması öğrenmeyi tetikliyor. En önemlisi teknoloji kullanım seviyesinin arttırması olumlu tarafıdır (Ö2). Uzaktan eğitim süreci benim için teknoloji kullanım seviyemi, sürekli yeni içerikler üretme isteğini artırdığın söyleyebilirim. Canlı derslerde de öğrencilerle birlikte tasarım yapılabiliyor. Hem de sinıftaki gürültü, konuşma, sessiz ol, malzemeleri unuttum öğretmenim gibi sorunlarda ortadan kalkmış oldu. Herkes kendi evinde rahat bir ortamda kendini ifade edebiliyor (Ö10).

Katılımcılar ( $\mathrm{f}=6)$ MTB uygulamalarında uzakta eğitim etkinliklerine katılımın sınırlı kaldığını bir sınırlılık durumu olarak belirtmişlerdir. MTB uygulamalarının uzaktan eğitim sırasında soyut kalması durumu ( $\mathrm{f}=4)$ katılımcılar tarafından üstünde durulan diğer husus olmuştur. Öğrencilerin evde bazı aletleri kullanmaları sırasında güvenlik riski oluşturması durumu da katılımcılar tarafından ( $\mathrm{f}=3$ ) bir sınırlılık olarak belirtilmiştir. 
Öğrencilerin katılımı istenen düzeyde olmamaktadır. Ben herkesin katılmasını istiyorum fakat bu mümkün olmuyor. Bir şey tasarlatmak istediğim zaman ise zaman zaman soyut kalıyor. Çocuğun çalşııken güvende olmasını istiyorum, örneğin maket bıçağı kullanırken kendine zarar verebilir diye sağlıklı yürütemiyorum (Ö3).

Uzaktan eğitim sürecinde MTB uygulamaların içeren kazanımların öğretimi oldukça soyut kalıyor. Bu kazanımları uygulamak yerine çeşitli görsel ile sözlü anlatım yaparak geçmek zorunda kalıyoruz (Ö9).

MTB uygulamalarında katılımcılar $(\mathrm{f}=3)$ olumsuz durum olarak 'kontrolsüz veli müdahalesi' olduğunu bildirmişlerdir.

Öğrencilere işlediğgimiz konudan yola çıkarak görevler verip evdeki malzemelerle tasarım yapmaların istiyorum. Sonra tasarımların fotoğraf ve videolarını Google classroom'a yüklüyorlar, bunları derste tek tek açı öğrencilerden dinleyip dönütler veriyorum. Ancak bunu öğretmenin ödev kontrolünü yalnız başına yapıp değerlendirmesi gerekirken dersin saatinden yiyor gibi gören veliler oldu (Ö1).

Veliler verdiğim mühendislik tasarım ödevlerine sürekli müdahale ediyor (Ö10).

Katılımcılar $(\mathrm{f}=2)$ tarafından sunulan öneriler arasında ise MTB etkinliklerinin senkron ve asenkron olarak yapılması yer almaktadır.

Uzaktan eğitimde MTB'nin daha işlevsel olması için çevrim içi ve çeorim dışı etkinliklerin eşgüdümlü olarak sürdürülmesi gerektiğgi inancındayım (Ö1).

Bence uzaktan eğitimi senkron ve asenkron şeklinde bölersek zaman açısından faydalı olur. Asenkron bölümde düz anlatım yerine çocuk etkileşimli uygulamalar ile öğrenir ve tasarımını yapar. Senkron bölümünde ise yapılan ürün ile ilgili bildirim verilir. Tartışılır (Ö9).

\section{Sonuç, Tartışma ve Öneriler}

Katılımcıların görüşleri incelendiğinde katılımcıların neredeyse tamamının 2018 FEBDÖP içerisinde yer alan MTB hakkında deneyim sahibi oldukları söylenebilir. Elde edilen verilerin alan yazın açısından yenilik getirdiği söylenebilir. Katılımcıların çoğu, bu alanda yapılan çalışmaların; problem çözme becerisini geliştirdiği, disiplinler arası entegrasyon ile öğrenme kalitesini arttırdı̆̆ı̆, mühendislik basamaklarını benimsetme noktasında bir altyapı oluşturduğu konusunda görüş bildirmiştir. 2018 FEBDÖP’ün ilk uygulandığı yıl yapılan bir araştırmada öğretmenlerin büyük çoğunluğunun MTB hakkında bilgi sahibi olmadıklarını bildiren bir sonuca ulaşılmıştır (Koç \& Kayacan, 2018). Bu sonucun, daha önce yapılan çalışmanın sonucu ile örtüşmediği görülmüştür. Geçen zaman diliminde Fen Bilimleri öğretmenlerinin MTB alanında çalışma yapabilme fırsatı bulmaları ve bu 
konuda uygulama yapmaları nedeniyle MTB hakkında bilgi sahibi olma noktasında görüşlerinin değiştiği söylenebilir.

Araştırmaya katılan öğretmenlerin çoğu MTB alanının teorik bir alt yapısının olmadığını belirtmişlerdir. Bu görüşler doğrultusunda MTB alanının temelde FeTeMM anlayışını temel aldığı fakat içinin yeterince doldurulmadığı noktasında bir sonuç ortaya çıkmaktadır. MTB alanının teorik altyapısının doldurulmaması, sadece uyarlanmış bir kavram ile sınırlı kaldığı görüşü belirlenmiştir. Katılımcı görüşleri ışığında ilgili öğretim programının MTB alanı ile ilgili açıklamalarına bakıldığında sadece ilgili alanı tanımladığı fakat yeterince açıklama olmadığı söylenebilir. Söz konusu durum ve katılımcı görüşleri dikkate alındığında MTB alanının altyapısının tam oturmadığı sonucu çıkarılabilir.

Katılımcıların çoğu kazanımların yazım şekli açısından yönlendirici ve açılayıcı özelliklere sahip olduğunu bildirmiştir. Fakat 2018 FEBDÖP, mühendislik tasarım beceri alanı kapsamındaki kazanımlar her ne kadar yönlendirici ve açılayıcı olsa da; birçok sorunla karşılaşıldığı sonucu ortaya çıkmıştır. Kazanımların sınırlayıcı, tutarsız ve de uyumsuz olduğu görüşünün çıkması dikkat çekici olmuştur. Katılımcılara göre; mühendislik kavramında derinleştirme önemlidir; fakat kazanımlardaki sınırlamalar konunun derinleştirilmesine imkân vermemektedir. Aynı zamanda 2018 FEBDÖP kazanımlarında yer alan sınırlamalar öğretim programının amaçlarıyla tutarsızlık oluşturduğu görüşü ortaya çıkmıştır. Katılımcıların görüşleri bağlamında öğretim programındaki bazı kazanımlar incelenmiştir. Yapılan incelemeler sonucunda örneğin; 8. Sınıf Fen Bilimleri Dersi "F.8.5.1.2: Basit makinalardan yararlanarak günlük yaşamda iş kolaylı̆̆g să̆layacak bir düzenek tasarlar." kazanımına ait açıklamada yer alan "ç: Matematiksel bağıntıya girilmez." şeklinde sınırlama görülmüştür (MEB, 2018). Aynı şekilde 2018 FEBDÖP'te giriş kısmındaki yetkinlikler bölümünde matematiksel yetkinliklerin öneminden bahsedilmektedir. Fakat program içerisinde kazanımlarda daha çok fen, mühendislik ve girişimcilik kavramlarının ön plana çıktığı görülmektedir. Teknoloji ve matematiksel süreç ile ilgili herhangi bir somut veri, açıklama ve yönlendirmenin hangi düzeyde ve nasıl ele alınacağına yönelik bir yönlendirme bulunmaması, bu konuda tutarlılık açısından bir sorun olarak görülebilir. Kazanım açıklamalarında yer alan "Matematiksel bağıntıya girilmez", "Matematiksel ilişki verilmez" ifadeler bu durumu yansıtmaktadır (Bahar vd., 2018). Mühendislik biliminin matematik ve teknoloji ile açık bir ilişkisi olduğu düşünüldüğünde bu sınırlamaların öğretim programına uyumsuzluk ve tutarsızlık olarak yansıdığını göstermektedir. Dolayısıyla bu durum, Fen 
Bilimleri öğretmenlerinin, MTB alanını tanımasını, derslerinde derinleştirerek vermesini zorlaştırmaktadır. Konu hakkında Elmas ve Gül (2020), yaptıkları araştırmada kazanımların tasarım süreci ile sınırlı kaldıklarını belirtmişlerdir. Başka bir çalışmada Özcan ve Koştur (2019), 2018 FEBDÖP içerisinde yer alan MTB'ye yönelik kazanımların oldukça yetersiz olduğunu belirtmişlerdir. Benzer şekilde Saraç ve Yıldırım (2019), yaptıkları araştırmada programın amaçları kısmında üzerinde önemle durulan MTB uygulamalarının kazanımlarla iyi bir şekilde ilişkilendirilemediğini ve bu durumun uygulama zorluğu oluşturduğu sonucuna varmışlardır.

MTB alanına dair katılımcılar alternatif ölçme ve değerlendirme etkinliklerine yer verilmesi gerektiğini bildirmiştir. Katılımcıların önemli bir bölümü 'Süreç Odaklı' değerlendirme yaptığını belirtmiştir. Sınırlı sayıda katılımcının 'Tasarım Şeması Odaklı' ve 'Sonuç Odaklı' puanlama yaptığını belirtmiştir. Katılımcılar, her ne kadar alternatif ölçme ve değerlendirme araçlarının kullanılması gerektiğini belirtse de; bu yaklaşımları yeterince uygulayamadıklarını aktarmışlardır. Dolayısıyla bazı durumların katılımcıları sınırladığı görülmektedir. Katılımcıların büyük bir bölümü MTB etkinliklerinde alternatif ölçme ve değerlendirme araçlarını kullanırken zaman sorunu yaşadı̆̆ını bildirmiştir. Bu durumun alternatif ölçme ve değerlendirme araçlarının kullanımının çok fazla zaman gerektirmesinden kaynaklanmıştır (Bol, 2002; Okur \& Azar, 2011). Katılımcıların en önemli sorun olarak zaman sorununu belirtmesinin söz konusu problem durumunu pekiştirdiği söylenebilir.

Ölçme ve değerlendirme bağlamında karşılaşılan diğer problem ise karne puanlamaların oranı ile ilgilidir. Dönem sonu notu hesaplanmasında yazılı sınavların ağırlıklı olması, öğrencilerin motivasyonunu bu konuda olumsuz etkilediği söylenebilir. Bu durum MTB alanına dair kazanımların alternatif ölçme ve değerlendirme araçları kullanılarak değerlendirilmesini güçleştirmektedir. Nitekim 2018 FEBDÖP, ölçme ve değerlendirme başlığında ölçme ve değerlendirmenin bireysel farklılıkları gözeterek ve azami çeşitlilik içerisinde yapılması gerektiği bildirilmektedir (MEB, 2018). Fakat dönem sonu puanlamasında yazılı sınavların, performans değerlendirmelerine oranla ağrılığının daha fazla olmasının olumsuzluklara yol açtığı söylenebilir. İlgili programdaki ölçme ve değerlendirme ile ilgili kapsamlı bir yönlendirme ve açıklama bulunmaması, söz konusu durumun öğretmen yeteneği ile ders kitaplarına bırakıldı̆̆ı söylenebilir. Cengiz'in (2019) 
FEBDÖP 2018 ile ilgili yaptığı araştırmada da katılımcıların bu konuda benzer noktalara değindikleri görülmüştür.

MTB alanı etkinliklerinde diğer disiplinler ile ilişkiler irdelendiğinde; katılımcılar MTB uygulamalarında en çok matematik disiplini ile ilişki kurduklarını açıklamışlardır. Fakat bu ilişkinin düzeyinin oldukça sınırlı olduğunu ve kazanım dışına taştığını belirtmişlerdir. Bu disiplin alanını görsel sanatlar disiplini takip etmiştir. Görsel sanatlar ile ilişkilendirme boyutunun ise herhangi bir teknik çizim boyutunda değil; teknik olmayan bazı görsel öğelerin betimlenmesi ile sınırlı kaldığı ortaya çıkmıştır. Az sayıda katılımcının da MTB uygulamaları çalışmalarını diğer derslerle ilişkilendirdiği söylenebilir. Fakat söz konusu ilişki sadece Fen Bilimleri dersinin içeriği dışına taşmamakta ve disiplinler arası bir boyutta olacak düzeyde değildir. Nitekim katılımcılar diğer ders öğretmenleri ile iş birliği kuramadığını bildirmiştir. Bahar vd. (2018) tarafından yapılan araştırmada 2018 FEBDÖP'te yer alan "disiplinler arası bakış" kavramının dersin içeriğine yeterince yansıtılamadığını belirtmiştir. Literatürdeki sonuç; bu araştırmadaki katılımcıların görüşleri ile örtüşmektedir. Söz konusu olumsuzluğa neden olan en önemli engel, diğer derslerin öğretim programlarının uyumsuzluğu olarak gösterilebilir.

Mühendislik eğitiminde tasarım ve prototipleme önemlidir. Üç boyutlu (3B) tasarım ve yazdırma hem hayal gücünü geliştirmekte hem de soyut kavramları somutlaştırarak öğrenme kalitesini arttırmaktadır. Dolayısıyla birçok alanda kullanılan 3B modellemenin eğitsel süreçlerde kullanılması fırsat haline gelmiş, zamanla da bir gereksinim haline gelmiştir (Demir, Caka, Tuğtekin, Demir, İslamoğlu \& Kuzu, 2016). Araştırmada katılımcıların tamamı 3B modelleme ve yazdırma konusunda farkındalığa sahip olduklarını bildirmiştir. Fakat katılımcıların sadece yarısı 3B modelleme konusunda bilgi sahibi olduğunu belirtmiştir. Dersinde daha önce 3B modellemeyi kullandığını belirten katılımcı sayısı ise bir kişi ile sınırlı kalmıştır. Söz konusu sınırlılığın ana nedeni olarak okulun ve sınıfların 3B modelleme için yeterli imkânı sağlayamaması olarak gösterilebilir. Yine katılımcıların önemli bir bölümünün 3B modellemenin mühendislik ve tasarım süreçleri için öneminin farkında olduğu; fakat bilgi ve deneyim eksikliği sorunu ile karşı karşıya kaldıkları görülmektedir. Okul ya da sınıfların 3B modelleme ve yazdırma sağlayabilecek teknolojilerle donatılması ve öğretmenlerin bu teknolojileri kullanabilecek potansiyele getirilmesi, öğretim programlarına entegre edilmesi özellikle MTB alanındaki öğrenme kalitesini arttıracaktır (Brown, 2015). Nitekim 3B modelleme ile yazıcıların öğrencilerin öğrenme motivasyonunu 
arttırdığı, dolayısıyla öğrenme kalitesini olumlu yönde etkilediği daha önce yapılmış çalışmalarda dile getirilmiştir (Kwon, 2017).

Katılımcılar okulun ve sınıfın fiziksel yapısının MTB uygulamaları açısından durumuna ilişkin görüş belirtmiş ve tamamı okul ve sınıfların olumsuz etkilerinden bahsetmişlerdir. Katılımcıların çoğu sınıfların fiziksel durumunun gözlem ve tasarım yapılmasına engel olduğunu bildirmiştir. Yine katılımcıların önemli bir kısmı fiziksel durumun, 21. yüzyıl becerilerinden uzaklaşma ve fırsat eşitsizliğini doğurduğunu açıklamıştır. Nitekim Türkiye'de sınıfların fiziksel yapısının ilkokul, ortaokul, lise düzeyinde standart ve tek düze olması bireysel farklılıklar açısından olumsuz olarak görülebilir (Şahan \& Taşdemir, 2019). Özcan ve Düzgünoğlu (2017) ilgili öğretim programının taslak hali üzerinde yaptıkları araştırmada öğretim programındaki içeriğin yansıtılması bağlamında sınıfların ve okulun fiziksel durumunun yetersiz olduğu, fırsat eşitsizliği oluştuğu ve öğretim programı hazırlanırken okulların altyapı yeterliliğinin dikkate alınmadığı görüşü ortaya çıkmaktadır. Söz konusu olumsuzlukların sınıf ortamında mühendislik temalı etkinliklerin yapılmasına engel olduğu söylenebilir. Roberts (2012)'de 20. yüzyılın sınıf ortamları ile istenen mühendislik becerilerinin kazandırılmasının mümkün olmadığını belirtmiştir. MEB son iki yılda Tasarım ve Beceri Atölyesi adıyla mühendislik becerilerine yönelik bazı kurumlara sınıflar açsa da bu durumun oldukça sınırlı kaldığı görülmektedir.

Covid-2019 pandemisi nedeniyle uzaktan eğitime geçilmiştir. Katılımcıları yarısı teknoloji disiplini ile ilişki kurma bağlamında olumlu katkısının olduğunu beyan etmiştir. Katılımcılar sınırlı da olsa bağımsız çalışarak özgün ürün oluşturma deneyimini sağladığını, öğrenciyi evde aktif kıldığını ve sınıfların fiziksel yetersizliğinin evdeki imkânlar aracıllğıyla kısmen de olsa aşıldığını dile getirmiştir. Bakioğlu ve Çevik (2020) tarafından Fen Bilimleri öğretmenleri ile yapılan araştırmada; uzaktan eğitimin teknoloji disiplininin kullanılma becerisini arttırdığı sonucu ortaya çıkmıştır. MTB uygulamaları uzaktan eğitim faaliyetlerinde katılımın az olması nedeniyle sınırlı olarak işlenebilmiştir. Aynı zamanda çalışmaların soyut kalması, güvenlik riski nedeniyle birçok etkinliğin yapılmaması çalışmaları sınırlandıran diğer unsur olarak gözükmektedir. Az sayıda katılımcı ise velilerin öğrenci tasarımlarına kontrolsüz bir şekilde müdahale etmesini olumsuz bir görüş olarak bildirmiştir. MTB alanına dair etkinliklerin uzaktan eğitim aracılığıyla işlendiğinde bu alana ilişkin etkinlikleri sınırlayan durumların olduğu ve olumsuz durumların daha fazla olduğu dikkat çekmektedir. Çalışmanın sonuçlarına bağlı olarak aşağıdaki öneriler yapılmıştır. 
- 2018 FEBDÖP içerisinde yer alan MTB alanının düzenlenmesi ve teorik altyapısının güçlendirilmesi önerilebilir.

- Kazanımlar yeniden ele alınarak Fen Bilimleri ve Matematik dersi arasındaki ilişki kazanımlara yansıtılmalıdır. Konu içerikleri, mühendisliğe uygun olarak derinleştirme firsatı sunmalıdir.

- 2018 FEBDÖP giriş kısmında yer alan MTB alanı açıklaması ile yetkinlikler bölümünde yer alan açıklamalar tutarlı hale getirilmelidir.

- Öğrencilerdeki motivasyonu arttırması için proje ve performans çalışmalarının dönem sonu puanına katkısı arttırılmalıdır.

- Disiplinler arası çalışma ortamının sağlıklı yürümesi için disiplinlerin ve öğretim programlarının birbiri ile uyumlu hale getirilmesi gerekir.

- Hizmet içi eğitimler aracılığıyla 3B modelleme ile ilgili öğretmen yetkinliğinin arttırılması, 3B modellemenin FEBDÖP MTB alanına entegre edilmesi öğrenme kalitesini arttıracaktır.

- Mühendislik temalı etkinliklerin sağlıklı yürütülmesi için sınıfların fiziksel yapısının iyileştirilmesi, teknolojik altyapının oluşturulması, atölyelerin kurulması, malzeme teminin sağlanması önem taşımaktadır.

- Mühendislik ve Tasarım süreçlerinde öğrencilerin ihtiyaçları ilçelere kurulacak bilim merkezleri ile sağlanabilir.

- Pilot uygulama olarak kaçış odaları, çocuk üniversitesi, etkileşimli sınıflar kurarak yararları ve etkileri gözlemlenebilir.

Etik Kurul Belgesi

Etik Kurul Komisyon Adı: Van Yüzüncü Yıl Üniversitesi Sosyal ve Beşeri Bilimler Etik

Kurul Başkanlığı

Etik Kurul Belge Tarihi: 25/03/2021

Etik Kurul Belgesi Sayı ve Numara: E-85157263-604.01.02-37614

Yazar Katkı Beyanı

Hasan Bakırcı: Kavramsallaştırma, metodoloji, verilerin toplanması, işlenmesi, analizi, yorumlanmasl, denetim, inceleme-yazma ve düzenleme.

Yusuf Kaplan: Kavramsallaştırma, metodoloji, verilerin toplanması, işlenmesi, analizi, yorumlanması, denetim, inceleme-yazma ve düzenleme. 


\section{Kaynaklar}

Ayas, A. (1995). Fen bilimlerinde program geliştirme ve uygulama teknikleri üzerine bir çalışma: İki çağdaş yaklaşımın değerlendirilmesi. Hacettepe Üniversitesi Eğitim Fakültesi Dergisi, 11(11), 149-155.

Ayas, A., Çepni, S., \& Akdeniz, A. R. (1993). Development of the Turkish secondary science curriculum. Science Education, 77(4), 433-440.

Bahar, M., Yener, D., Yılmaz M., Emen, H., \& Gürer, F. (2018). 2018 Fen bilimleri öğretim programı kazanımlarındaki değişimler ve fen teknoloji matematik mühendislik (STEM) entegrasyonu. Abant İzzet Baysal Üniversitesi Ĕgitim Fakültesi Dergisi, 18(2), $702-$ 735.

Bakırcı, H., \& Kutlu, E. (2018). Fen bilimleri öğretmenlerinin FeTeMM yaklaşımı hakkındaki görüşlerinin belirlenmesi. Türk Bilgisayar ve Matematik Ĕ̆itimi Dergisi, 9(2), 1-20.

Bakioğlu, B., \& Çevik, M. (2020). Covid-19 pandemisi sürecinde fen bilimleri öğretmenlerinin uzaktan eğitime ilişkin görüşleri. Turkish Studies, 15(4), 109-129.

Bol, D. J. (2002), The use of alternative assessments in the physical education classroom (Master's thesis). The California State University, Fullerton, U.S.A.

Brown, A. (2015). 3D Printing in instructional settings: Identifying a curricular hierarchy of activities. Tech Trends, 59(5), 16-24.

Cengiz, E. (2019). Fen bilgisi öğretmenlerinin 2018 yılında güncellenen fen bilimleri (5, 6, 7 ve 8) dersi öğretim programına ilişkin düşünceleri. Academia Ĕ̆itim Araştırmaları Dergisi, $4(2), 125-141$.

Cresswell, J. (2012). Educational research. Boston: Pearson Education.

Çepni, S. (2018). Araştırma ve proje çalışmalarına giriş (8. Baskı). Trabzon: Celepler Matbaacılık.

Demir, E. B. K., Çaka, C., Tuğtekin, U., Demir, K., İslamoğlu, H., \& Kuzu, A. (2016). Üç boyutlu yazdırma teknolojilerinin eğitim alanında kullanımı: Türkiye'deki uygulamalar. Ege Ĕ̆itim Dergisi, 2(17), 481-503.

Demirci, B. (1993). Çağdaş fen ve eğitim bilimcileri. Hacettepe Üniversitesi Eğitim Fakültesi Dergisi, 9, 155-160.

Elmas, R., \& Gül, M. (2020). STEM eğitim yaklaşımının 2018 fen bilimleri öğretim programı kapsamında uygulanabilirliğinin incelenmesi. Türkiye Kimya Derneği Dergisi Kısım C: Kimya Ĕ̆itimi, 5(2), 223-246.

Gözütok, F. D. (2003). Curriculum development in Turkey. W. F. Pinar, (Ed.), International handbook of curriculum research (s. 607-622) içinde. London: Lawrence Erlbaum Associates.

Harari, Y. N. (2018). 21. yüzyıl için 21 ders. (Çev: S. Siral). İstanbul: Kolektif Kitap.

Koç, S. R., \& Kayacan, K. (2018). Fen bilimleri öğretmenlerinin 2018 fen bilimleri öğretim programında yer alan mühendislik ve tasarım becerilerine ilişkin görüşlerinin belirlenmesi. Electronic Turkish Studies, 13(19), 865-881.

Krefting, L. (1991). Rigor in qualitative research: the assessment of trustworthiness. The American Journal of Occupational Therapy, 45(3), 214-222.

Kwon, H. (2017). Effects of 3D printing and design software on students' overall performance. Journal of STEM Education: Innovations and Research, 18(4), 37-42. 
Miles, B. M., \& Huberman A. M. (1994). Qualitative data analysis: An expanded source book. California, USA: Sage Publications.

Milli Eğitim Bakanlığı [MEB]. (2005). İlköğretim fen ve teknoloji dersi (6, 7 ve 8. sinfflar) öğretim programı. Ankara: Devlet Kitapları Basım Evi.

Milli Eğitim Bakanlığı [MEB]. (2013). İlköğretim kurumları fen bilimler dersi (3, 4, 5, 6, 7 ve 8. sınıflar) öğretim programı. Ankara: Devlet Kitapları Basım Evi.

Milli Eğitim Bakanlığı [MEB]. (2018). Fen bilimleri dersi (3, 4, 5, 6, 7 ve 8. Sinıflar) öğretim programı. Ankara: Milli Eğitim Bakanlığı Yayınevi.

Okur, M., \& Azar, A. (2011). Fen ve teknoloji dersinde kullanılan alternatif ölçme ve değerlendirme tekniklerine ilişkin öğretmen görüşleri. Kastamonu Ĕ̆itim Dergisi, 19(2), 387-400.

Özcan, H., \& Düzgünoğlu, H. (2017). Fen bilimleri dersi 2017 taslak öğretim programına ilişkin öğretmen görüşleri. International Journal of Active Learning, 2(2), 28-47.

Özcan, H., \& Koştur, H. İ. (2019). Fen bilimleri dersi öğretim programı kazanımlarının özel amaçlar ve alana özgü beceriler bakımından incelenmesi. Trakya Eğitim Dergisi, 9(1), 138-151.

Roberts, A. (2012). A justification for STEM education. Technology and Engineering Teacher, $71(8), 1-4$.

Saraç, E., \& Yıldırım, M. (2019). 2018 fen bilimleri öğretim programına yönelik öğretmen görüşleri. Academy Journal of Educational Sciences, 2, 138-151.

Şahan, E., \& Taşdemir, M. (2019). Ortaokul fen bilgisi programının değerlendirilmesi: Okul farklılıkları açısından bir durum çalışması. Electronic Turkish Studies, 14(4), 2659-2683.

Toraman, S., \& Alcı, B. (2013). Fen ve teknoloji öğretmenlerinin yenilenen fen bilimleri dersi öğretim programına ilişkin görüşleri. Ekev Akademi Dergisi, 17(56), 11-22.

Türk Eğitim Derneği Düşünce Kuruluşu [TEDMEM]. (2013). 2005 ve 2013 Fen programları ve felsefi temelleri. https://tedmem.org/blog/2005-ve-2013-fen-programlari-ve-felsefitemelleri-uzerine 15/11/2020 adresinden alınmıştır.

Ürey, M., \& Cerrah Özsevgeç, L. (2015). Sınıf öğretmen adaylarının fen bilgilerini günlük yaşamla ilişkilendirebilme düzeyleri ile fen tutum ve okuryazarlıkları arasındaki ilişki. Kuramsal Eğitimbilim Dergisi, 8(3), 397-420. 


\section{Ek-1: Yarı Yapılandırılmış Mülakat Formu}

1. Mühendislik ve Tasarım Becerileri hakkında ne düşünüyorsunuz?

2. Mühendislik ve Tasarım Becerileri uygulamalarında dersin konu/kazanımları sizi nasıl yönlendiriyor?

3. Mühendislik ve Tasarım Becerileri uygulamalarında ölçme ve değerlendirme deneyimleriniz nelerdir?

4. Mühendislik ve Tasarım Becerileri uygulamalarında diğer disiplinlerden faydanlanma deneyimleriniz nelerdir?

5. Mühendislik ve Tasarım kapsamındaki uygulamalar sırasında kullanılan 3 boyutlu modelleme (3B Modelleme) hakkında ne düşünüyorsunuz?

6. Okulun ve sınıfların fiziksel yapısı Mühendislik ve Tasarım Becerileri Uygulamalarını nasıl etkilemektedir? Daha etkili uygulanabilmesi için öneriniz nedir?

7. Uzaktan eğitim sürecinde Mühendislik ve Tasarım Becerileri uygulamalarını içeren kazanımların öğretimi sırasındaki deneyimleriniz nelerdir? 